\title{
Deconstructing AMO framework: A systematic review
}

\author{
Juan A. Marin-Garcia (iD) ${ }^{1}$, Juan Martinez Tomas (iD ${ }^{2}$ \\ ${ }^{1}$ ROGLE. Universitat Politècnica de València (Spain) \\ ${ }^{2}$ Universitat Politècnica de València (Spain) \\ jamarin@,omp.upv.es,juamarto@,euitiv.upv.es
}

Received July, 2016

Accepted August, 2016

\section{Abstract}

Purpose: The AMO framework has been widely accepted in HRM literature for explaining the linkage between human resources practices and performance. However, it remains unclear whether this model has been fully demonstrated or not. Hence, we propose a systematic review that aims at identifying those investigations that have thoroughly tested the model, as well as the approaches used by them.

Design/methodology: Systematic literature review, filtering scientific papers published in journals indexed in Scopus, Web of Science or Google Scholar, from the year 1993 to 2016, in the field of Social Sciences and Humanities with research that indirectly apply the AMO model in their analysis.

Findings: AMO model is an excellent and structured framework that provides a better understanding of the relationship between HRM and performance. Moreover, the effectiveness of the model's proposal appears to be beyond doubt. In fact, a well trained and skilled employee will perform better, and a motivated worker will be ready to "go the extra mile". Likewise, if the work environment does not provide adequate opportunities, both abilities and motivation might become meaningless. However, we consider that many other factors could influence the positive effects of HPWS. As a matter of fact, not only contextual factors, but 
also individual beliefs, personal affinities, or personal circumstances (among others) might affect the implementation of these practices and the subsequent outcomes. For this reason, we consider that developing an HRM model that perfectly fit any situation is a very complicated, if not impossible, task.

Research limitations/implications: The results show a significant variability in both research approaches and variables taken into consideration. In addition, it seems that little research has been conducted to verify the AMO model directly. Therefore, we consider that there is a great need to study the model from a more systematic perspective. A thorough understanding of the model could lead to a better understanding of the problems that organizations face when implementing human resource practices.

Originality/value: Our study shed light on some aspects of the AMO framework within the HRM context. Specifically, we aimed to identify whether or not it is possible to confirm the model as it was originally proposed. We also find out which HR practices and measures of performance were considered across investigations, to define a standard approach.

Keywords: Systematic literature review, Human resources management, High-performance work practices, High-performance work systems, AMO framework, Ability-motivation-opportunity model, Organizational performance

Jel Codes: O15, M50

\section{Introduction}

Since its emergence in 2000, the ability, motivation and opportunity (AMO) framework (Appelbaum, Bailey, Berg \& Kalleberg, 2000; Boxall \& Purcell, 2003) has been largely accepted for explaining the linkage between human resources management and performance. In fact, many of the articles published after 2000 that explore the HRM-performance linkage use this theoretical framework either explicitly or implicitly (Boselie, Dietz \& Boon, 2005; Ehrnrooth \& Björkman, 2012; Hutchinson, 2013; Paauwe \& Boselie, 2005).

According to some authors, the origins of the model lie in the theoretical discourse between industrial psychologists, who assume that performance is a function of training and selection (thus ability), and 
social psychologists, who believe that motivation is essential to ensure performance (Maclnnis \& Jaworski, 1989). Later, Vroom (1964) adopted an interactive relationship considering both ability and motivation, and explaining performance by the function $\mathrm{P}=\mathrm{f}(\mathrm{A} \times \mathrm{M})$ (Blumberg \& Pringle, 1982). As can be seen, this function considered that only personal dimensions affect performance, and was not capable of explaining the external environment effect. With the aim of solving this issue, Blumberg and Pringle (1982) developed a new model, broadening the concepts of motivation and ability, and introducing a new one: opportunity, which they considered the missing dimension. As a result, performance was a function of capacity to perform (including different variables such as age, knowledge, level of education and energy level), willingness to perform (including variables such as motivation, job satisfaction, personality, values, and expectations), and opportunity to perform (that included variables such as working conditions, tools, materials, leader behavior, procedures and time) (Blumberg \& Pringle, 1982). These authors pointed out that all three elements (opportunity, capacity, and willingness) must be present for performance to occur, assuming an interactive model $(\mathrm{P}=\mathrm{f}(\mathrm{O} \times \mathrm{C}$ $\mathrm{x}$ W)). Also, low levels of any of the dimensions would considerably decrease levels of performance (Blumberg \& Pringle, 1982).

The AMO framework was initially proposed by Bailey (1993), who suggested that ensuring the employee's discretionary effort needed three components: employees had to have the necessary skills, they needed appropriate motivation and employers had to offer them the opportunity to participate (Appelbaum et al., 2000). Based on this model, and drawing on the concept of high performance work systems (HPWS), the model was later developed by Appelbaum, Bailey, Berg and Kalleberg (Appelbaum et al., 2000), and its acronym stands for the three elements that enhance together employee performance: individual ability (A), motivation (M), and the opportunity to participate (O) (Bayo-Moriones \& Galdon-Sanchez, 2010; Boselie, 2010; Claudia, 2015; Knies \& Leisink, 2014; Kroon, Van De Voorde \& Timmers, 2013; Munteanu, 2014). According to the model, people perform well when they have the capabilities, they have the adequate motivation, and their work environment provides opportunities to participate (Boselie, 2010; Boxall \& Purcell, 2003; Choi, 2014; Marín-García, Miralles, Garcia-Sabater \& Perello-Marin, 2011; Marín-García, 2013; Raidén, Dainty \& Neale, 2006).

Hence, the model is comprised of basic concepts of psychology (Kroon et al., 2013), which are related to three systems that shape individual characteristics: ensuring that employees have the appropriate abilities, motivating employees to enhance discretionary behavior, and empowering them toward organizational outcomes (Harney \& Jordan, 2008). Ability dimension is usually defined by the acronym KSA (knowledge, skills and abilities) (Fu, Flood, Bosak, Morris \& O’Regan, 2013). Thus, Ability- 
enhancing practices aim to improve those three components. Examples of these practices are employee recruitment techniques or formal training (Kroon et al., 2013; Raidén et al., 2006). Motivation deals with an employee desire to perform, which can be enhanced by extrinsic or intrinsic motivation. Examples of motivation-enhancing practices are incentives or career opportunities (Munteanu, 2014; Raidén et al., 2006). The AMO model introduces as well the opportunity dimension, on the basis of job design theories (Hackman \& Oldham, 1980; Kroon et al., 2013), or empowerment literature (Gerhart, 2005; Kroon et al., 2013). Hence, opportunity takes into consideration not only individual characteristics but also the work environment. Practices contributing to the opportunity dimension are, for instance, quality circles or team working.

The model has evolved and improved over successive studies. As a matter of fact, some authors consider that AMO influence in performance is more complicated than expected, because it depends not only on the existence of a set of practices (HRM content) but also on the employee subjective perceptions of these practices (Boxall \& MacKy, 2009; Ehrnrooth \& Björkman, 2012; Lepak, Liao, Chung \& Harden, 2006; Wright \& Nishii, 2007). That is to say; we must distinguish between intended, actual and perceived HRM (Vermeeren, 2010). Moreover, some authors point out that the employeebased perspective adopted by the AMO model could be better explained from a managerial perspective (Bos-Nehles, Van Riemsdijk \& Kees Looise, 2013). This view claims that well-designed HR bundles of practices do not guarantee an effective implementation, and focus on line manager's capacities to implement HR practices (A), their motivation to enable them (M), and the organizational support for undertaking the changes needed (O) (Bainbridge, 2015; Ozcelik \& Uyargil, 2015). Besides, the variety of practices and measures of performance across investigations, make it difficult to state firm conclusions about which approach is decisive for performance. In fact, the selection of practices seem to be based more on intuition about their influence over performance, than on substantial empirical evidence (Wood, Burridge, Rudloff, Green \& Nolte, 2015). As a result, it remains unclear which are the linking mechanisms between bundles of practices and organizational outcomes (Jiang, Lepak, Hu, Baer, Jia \& Baer, 2012; Renwick, Redman \& Maguire, 2013; Vermeeren, 2010). Finally, although many investigations mention the AMO model in their theoretical framework, not all of them test the model in their further analysis and, even doing it; it seems that many of them do not apply the model as it was first proposed.

Taking all the above into account, as well as the importance of the AMO model in the human resources literature, we consider that it is necessary to conduct an investigation to shed light on some fundamental issues concerning the AMO framework. Hence, this study aims to find out those studies 
that have thoroughly tested the model, as well as the approach used by them (e.g. multiplicative or summative). Furthermore, it also aims to clarify how different authors measure the effectiveness of the model, that is to say, which HR practices and measures of performance they use in their analysis. Finally, another objective of this research is to determine whether the AMO framework is useful or not in explaining the linkage between HRM and performance in different context.

We have divided the study as follows. The first section deals with the introduction. The second section outlines the conceptual framework, explaining the important concept, as well as identifying the interrelationships among them. The third section details the methodology carried out, which as the title states is a systematic literature review. The aim of this review is to ensure a structured and replicable work that will help us to both state the research questions and identify the current state-of-the-art in the field of study. In the fourth section, the results of the study are examined, with the aim of answering thoroughly to questions raised. Finally, the fifth section is devoted to state the conclusions and possible future research.

\section{Conceptual framework}

The following conceptual framework (Figure 1) aims to understand how the concepts involved in this study fit and work together. This framework takes into consideration several concepts explained below.

Human resource management (HRM) is defined as the design of employment systems that include a set of policies intended to maximize employee performance and commitment, in order to meet the organization goals (Alagaraja, 2012; Guest, 1997). Several factors shape HRM (see Figure 1), for instance, the external environment (e.g. economic conditions, competitors), the organizational strategy (e.g. low cost or focus differentiation strategy) and the organizational characteristics themselves (e.g. industry sector, organization size, management style). During the last decades, HRM research has explored the linkage between human resources practices and performance. As a result, several studies have documented a positive relationship between the use of HPWS and business performance (Appelbaum et al., 2000; Arthur, 1994; Block \& Pickl, 2014; Demortier, Delobbe \& El Akremi, 2014; Guthrie, Flood, Liu \& MacCurtain, 2009; Huselid, 1995; Jiang, Lepak, Han, Hong, Kim \& Winkler, 2012; Knies \& Leisink, 2014; MacDuffie, 1995; Rabl, Jayasinghe, Gerhart \& Kühlmann, 2014a).

The term high-performance work practices (also referred in the literature as high-commitment management, high-involvement management or innovative work practices (Bayo-Moriones \& Galdon- 
Sanchez, 2010; Marín-García \& Conci, 2012)) apply to a broad set of human resource practices that aim to make organizations more participative and flexible, with the objective of being capable of competing in the current environment (Kalleberg, 2006). The HIW practices include three dimensions: skill requirements, jobs designed to use those skills, and an incentive structure to induce discretionary effort (Appelbaum et al., 2000). These practices are intended to increase business performance by enhancing employee ability, motivation and opportunity to contribute (Bayo-Moriones \& GaldonSanchez, 2010; Rabl, Jayasinghe, Gerhart \& Kühlmann, 2014). Moreover, implementing these practices leads to ensuring that all employees are in a position to contribute towards the goals of the organization (Ashton \& Sung, 2002), cited in Robineau, Ohana\&Swaton (2015).

Additionally, high-performance work systems (HPWS) (also known as "high commitment management" (Arthur, 1994; Choi, 2014) or "HR practice configurations" (Choi, 2014; Delery, 1998) are a combination of HPW practices, which are hypothesized to create synergistic effects (BayoMoriones \& Galdon-Sanchez, 2010; Della Torre \& Solari, 2013; Marín-García \& Conci, 2012; Rabl et al., 2014). According to these synergies, performance obtained by using bundles of practices will be greater than the sum of individual effects achieved by applying separately each of them (An, 2009; Boxall, Purcell \& Wright, 2009; Demortier et al., 2014; Drummond \& Stone, 2007; Jiang, Lepak, Hu, et al., 2012; Minbaeva, 2013). As a matter of fact, introducing self-managed work teams without the support of management and proper training will reduce the results expected from teamwork (Kroon et al., 2013; MacDuffie, 1995). In the same vein, other authors point out neither ability nor motivation alone can lead to the highest performance (Sarikwal \& Gupta, 2013).

Many authors support the synergistic effect hypothesis. However, there is no consensus in determining which specific practices must form the HPWS bundle. In fact, practices taken into consideration differ from one investigation to another (Kroon et al., 2013). In this regard, some authors point out that transferability of HIWS becomes impossible, as those systems must be more or less customized to meet the requirement of each particular context (Ehrnrooth \& Björkman, 2012). This view is known as the contingency theory, and states that the efficacy of such systems depend on many factors, including external environment, internal consistency and coherence (systems developed taking into the account the nature of the firm) and dynamism (systems are capable of evolving as companies change) (Ehrnrooth \& Björkman, 2012). In other words, the contingency theory defends the "best fit" approach in contrast to the universalistic view, which considers the "best practice" approach.

Also, there is not a clear consensus for explaining the precise mechanisms of how HR systems work to reach the objectives (Block \& Pickl, 2014; Demortier et al., 2014; Guest, 2011; Messersmith, Patel \& 
Lepak, 2011). This mystery is popularly known as the "black box" of HRM (Gerhart, 2005; Harney \& Jordan, 2008; Innocenti, Pilati \& Peluso, 2011). In this respect, Boselie et al. (2005) conducted a literature review to analyse the linkages between HRM and performance between 1994 and 2003, and found that many studies acknowledge the existence of the "black box", but few of them tried to look inside it (Boselie et al., 2005).

The AMO framework has been considered by many authors as a useful tool for understanding the HRM-performance linkage or, in other works, opening the so-called black box (Boselie et al., 2005; Demortier et al., 2014; Knies \& Leisink, 2014). However, some authors point out that this issue should be handled in a more comprehensive way (from a contingent perspective), by integrating mediating variables. Examples of mediating variables are: employee's individual characteristics (e.g. attitudes and behaviour (Block \& Pickl, 2014; Gardner, Moynihan, Park \& Wright, 2001; Kehoe \& Wright, 2013)), line-managers features (e.g. leadership style or affective commitment (Demortier et al., 2014)), or organizational level dimensions such as climate or culture (Gelade \& Ivery, 2003) cited in Demortier et al. (2014).

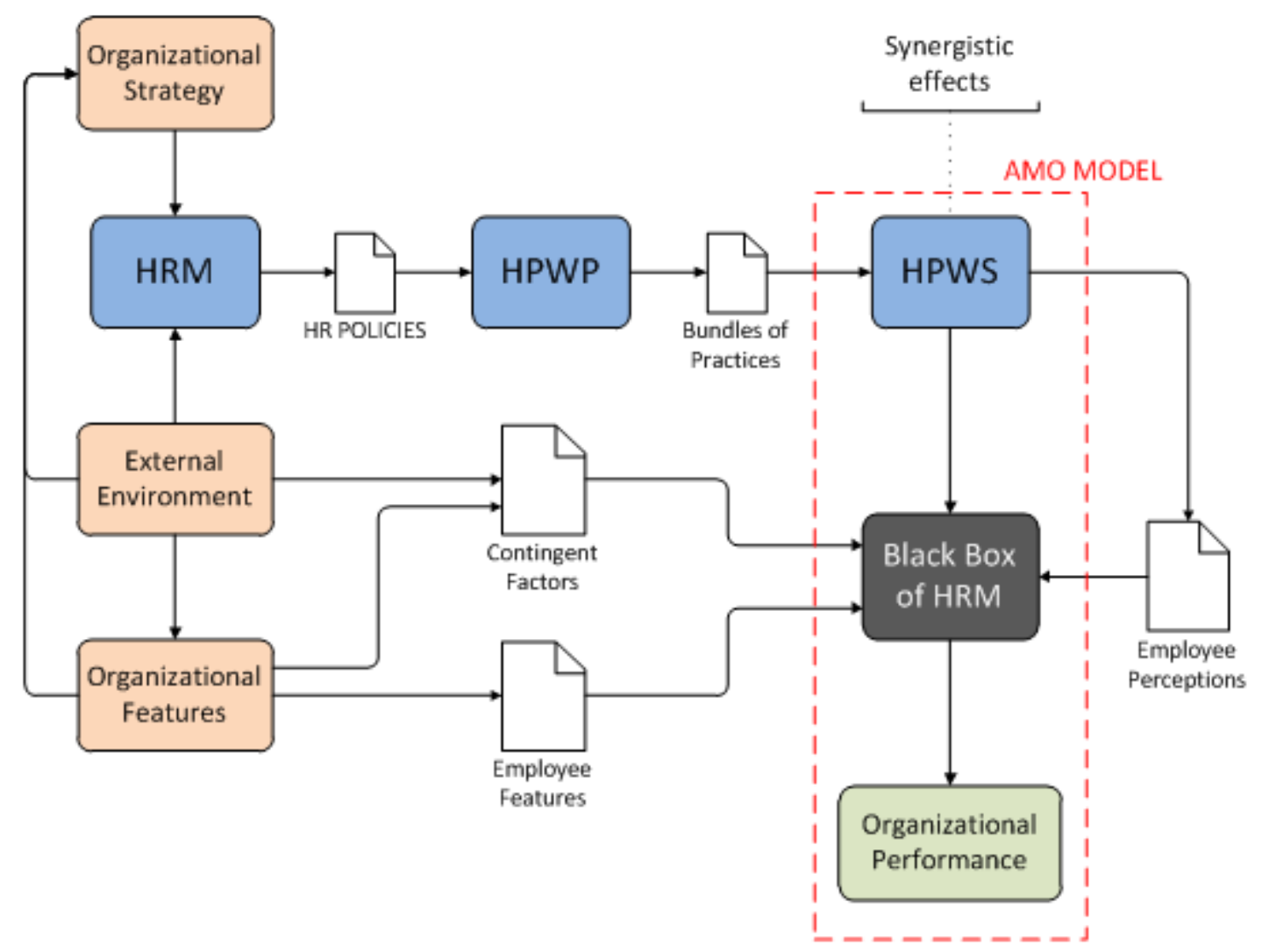

Figure 1. Conceptual Framework 


\subsection{Why is important to do this review?}

The aim of this study is to identify whether or not the AMO framework hasbeen fully confirmed in the way it was first proposed. We consider that it is an interesting issue because the AMO framework is widely accepted in human resource management for explaining the linkage between high involvement work practices and performance. Therefore, a thorough understanding of the model could lead to a better understanding of the problems that organizations face when implementing human resource practices.

As far as this objective is concerned, it is essential first to analyze the original model and its orientation in the field of human resources management. That is to say; we must know what the authors proposed to have it as a starting point for the investigation.

Furthermore, it is also important to identify those investigations that have been conducted with the specific objective of validating the model. Likewise, it is also important to exclude those studies citing the AMO model in their theoretical framework, but not apply it in their further analysis. As we do not expect to find many investigations that directly test the model, we decided to include also those articles that indirectly verify the model in their analysis.

Finally, the study must provide information regarding which ability, motivation, and opportunityenhancing practices have been considered through different studies, as well as how organization performance have been measured. Identifying those factors is critical to provide an extensive overview of the current state-of-the-art.

\section{Methodology}

We started this study by setting up a searching protocol, with the aim of synthesizing the best available research concerning AMO framework in human resource management field. Moreover, this systematic review protocol uses transparent procedures for ensuring a structured work that could be easily replicated in future research. Finally, this searching protocol was also designed to minimize bias (Delgado Rodríguez, 2010; Marín-García, Ramirez Bayarri \& Atares Huerta, 2015; Medina-López, Alfalla-Luque \& Marín-García, 2011; Medina-López, Marín-García \& Alfalla Luque, 2010).

For that reason, we first posed the above issue: "Why is important to do this review?" that led us to identify several research questions. Next, we defined the inclusion and exclusion criteria, as well as the 
keywords related to this research. The automatic search was conducted in three databases (Scopus, Web of Science, and Google Scholar) and later on, we defined a filtering methodology for codifying and selecting those articles relevant to the study. Finally, we created a template for extracting information in a structured manner and being able to answer our research questions. The whole process is described below.

\subsection{Inclusion and exclusion criteria of this review}

\subsubsection{Inclusion criteria}

- Scientific papers in journals indexed in Scopus, Web of Science or Google Scholar.

- Articles or reviews published from the year 1993 to 2016, in the field of Social Sciences and Humanities, especially those related to the human resources management.

- Articles written in English or Spanish.

- Research conducted with the specific objective of validating the AMO framework.

- Research that indirectly apply the AMO model in their analysis; linking abilities, motivation, and opportunity enhancing practices to performance.

\subsubsection{Exclusion criteria}

- Articles or reviews published before 1993.

- Articles written in languages other than English or Spanish.

- Research not related to human resources management.

- Research that does not apply the AMO model in their analysis, even when they name it in the theoretical framework.

- Research related to AMO framework for explaining consumption patterns, consumer behavior, consumer psychology, advertisement strategies or marketing approaches. 


\subsection{Searching Protocol}

We structured the searching protocol in four different stages: Identification, screening, eligibility and Inclusion. The following PRISMA diagram (Figure 2) shows all these phases graphically:

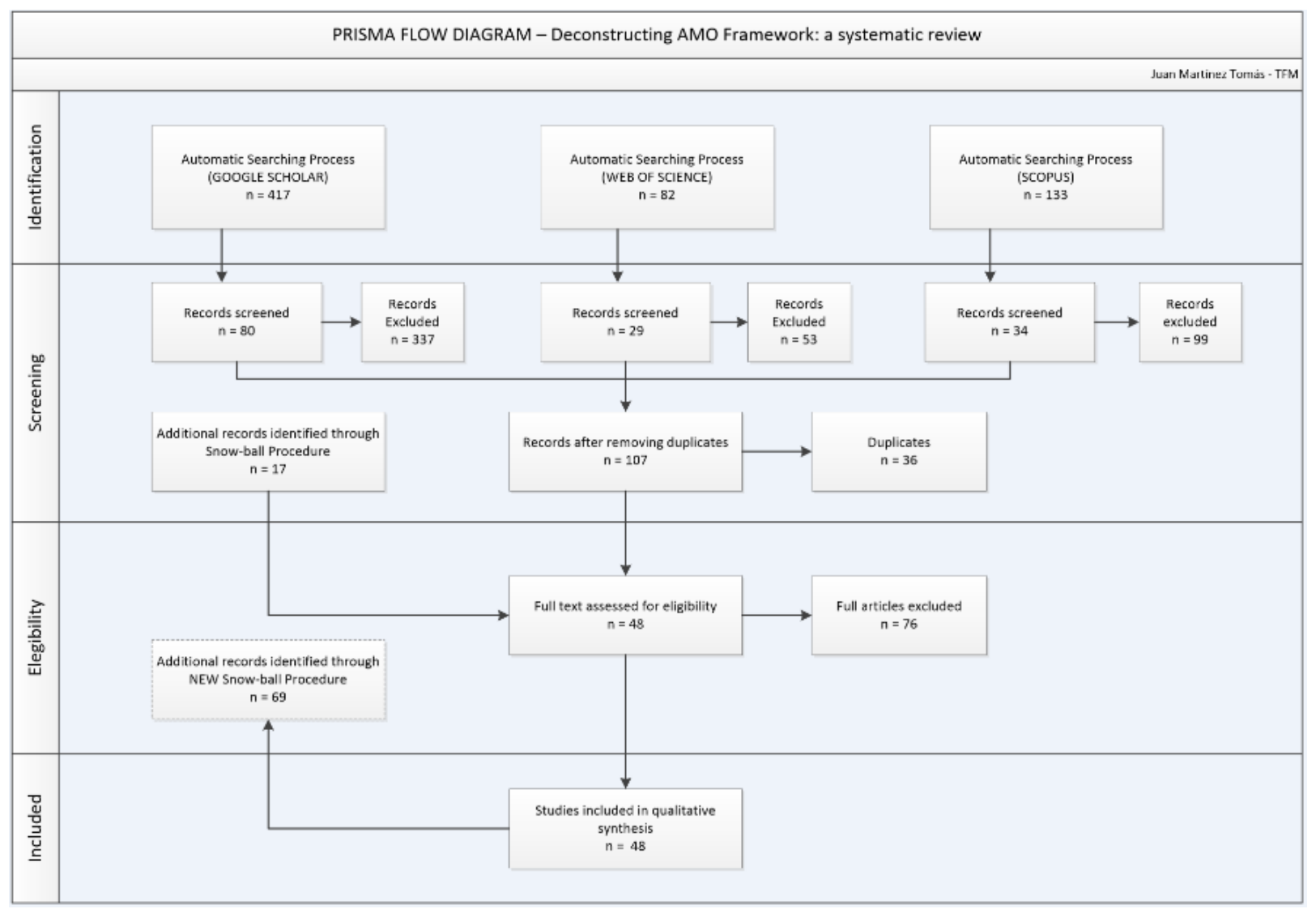

Figure 2. Prisma flow diagram

In the Identification stage, the results have been drawn from searches conducted in Scopus, Web of Science and Google Scholar, as can be seen in the table below (Table 1). In both Scopus and Web of Science, the results were obtained by using the terms ability, opportunity, and motivation, in combination with the terms HRM and human resources.

In Google Scholar we used the following strategies: 
- 1st search: articles that explicit mention Bailey's 1993 article "Discretionary effort and the organization of work: employee participation and work reform since Hawthorne", which is supposed to be the origin of AMO framework in the context of human resources (10 results).

- 2nd search: articles citing the article above (cited by 233), as well as containing the term AMO (21 results)

- 3rd search: results obtained by using the terms ability, motivation, and opportunity, as well as the term Bailey (125 results).

- 4th search: results obtained by using the terms AMO framework, AMO model or AMO theory in combination with the terms HRM and human resources. Also, we added the term Bailey, with the aim of reducing the results obtained (261 results).

\begin{tabular}{|c|c|}
\hline Scopus & Results \\
\hline $\begin{array}{l}\text { TITLE-ABS-KEY (amo AND ( theory OR framework OR model)) AND DOCTYPE (ar OR re) } \\
\text { AND SUBJAREA (mult OR arts OR busi OR deci OR econ OR psyc OR soci) AND } \\
\text { PUBYEAR > } 1999\end{array}$ & 31 \\
\hline $\begin{array}{l}\text { (TITLE-ABS-KEY ((ability W/3 motivation W/3 opportunity)) OR TITLE-ABS-KEY ((amo AND } \\
\text { (human OR hr)))) AND DOCTYPE (ar OR re) AND SUBJAREA (mult OR arts OR busi OR } \\
\text { deci OR econ OR psyc OR soci) AND PUBYEAR > } 1988\end{array}$ & 102 \\
\hline Web of Science & Results \\
\hline $\begin{array}{l}\text { TOPIC: (((ability near/3 motivation near/3 opportunity) OR (amo AND ( human OR hrm)))) } \\
\text { Refined by: WEB OF SCIENCE CATEGORIES: (BUSINESS OR MANAGEMENT OR } \\
\text { PSYCHOLOGY SOCIAL OR INDUSTRIAL RELATIONS LABOR OR OPERATIONS RESEARCH } \\
\text { MANAGEMENT SCIENCE OR ENGINEERING MANUFACTURING OR ECONOMICS OR } \\
\text { BUSINESS FINANCE OR ENGINEERING INDUSTRIAL) } \\
\text { Indexes=SCI-EXPANDED, SSCI, A\&HCI, CPCI-S, CPCI-SSH, ESCI Timespan=All years }\end{array}$ & 82 \\
\hline Google Scholar & Results \\
\hline 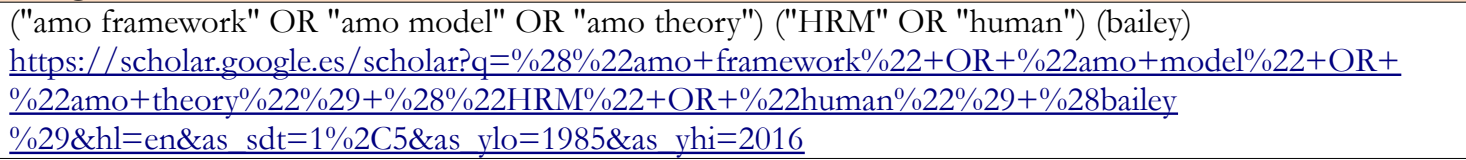 & $\begin{array}{r}261 \\
\text { (Stop 180) }\end{array}$ \\
\hline $\begin{array}{l}\text { Ability-Motivation-Opportunity bailey } \\
\text { https://scholar.google.es/scholar?q=Ability-Motivation- } \\
\text { Opportunity+bailey\&hl=es\&as sdt=0\&as vis=1\&oi=scholart\&sa=X\&ved=0ahUKEwj5yPLfk DKAhWC } \\
\text { sxQKHT2UDBEQgQMIHjAA }\end{array}$ & $\begin{array}{r}125 \\
\text { (Stop 80) }\end{array}$ \\
\hline 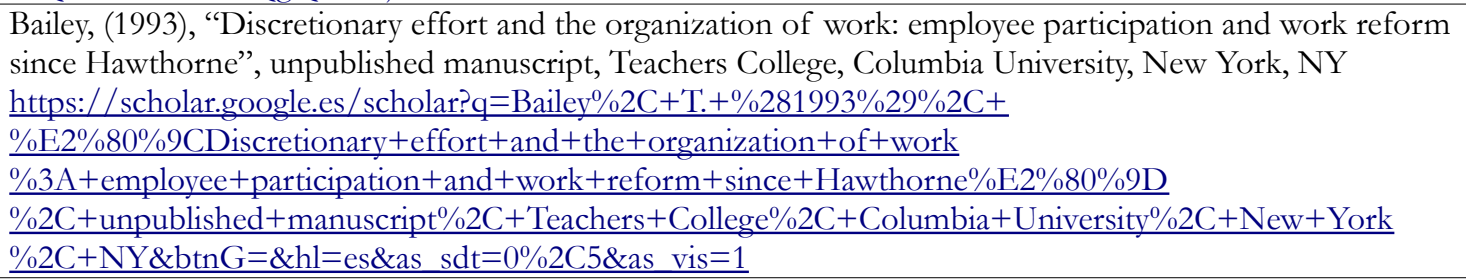 & 10 \\
\hline $\begin{array}{l}\text { "Discretionary effort and the organization of work: employee participation and work reform since } \\
\text { Hawthorne". Cited by 233. Search "AMO" within citing articles. } \\
\text { https://scholar.google.es/scholar? }\end{array}$ & 21 \\
\hline
\end{tabular}

Table 1. Automatic Search Strategy (Search conducted in February 2016) 
During the screening stage, with the aim of avoiding to exclude references that could meet the criteria, we decided to filter them manually by using the following methodology:

- Sort the articles by relevance.

- Review both titles and abstracts, excluding those articles that are clearly not related to the objectives explained above.

- Review both titles and abstracts, selecting those articles that could meet the inclusion criteria defined above. Store these resultsin a reference manager software (Mendeley) for further review.

- Download the full text of the documents selected in this first stage.

- Taking into consideration the filtering limitations of Google Scholar and the large number of results obtained in both the third and the fourth search strategies, we decided to stop the search in the page where no reference met our inclusion criteria.

The articles selected in this stage were stored in three different folders of Mendeley for each of the databases used. For that reason, the last action within the filtering stage was checking for duplicates and excluding them.

In the eligibility stage, we proceeded to the filtering process of the selected documents, using the following method:

- Sorting the references by title in alphabetic order, with the aim of minimizing potential bias caused by factors such as relevance or year of publication.

- We classify references starting from the first one (according to the title and abstract) with the following codification (Table 2): 


\begin{tabular}{|c|c|c|c|}
\hline Code & Definition & When to use & Action \\
\hline A. Approved & $\begin{array}{l}\text { The title and the abstract } \\
\text { are clearly related to the } \\
\text { objectives of the study. }\end{array}$ & $\begin{array}{l}\text { When the article meets the } \\
\text { inclusion criteria and does } \\
\text { not affect the exclusion } \\
\text { criteria. }\end{array}$ & $\begin{array}{l}\text { Include the article in the } \\
\text { list of references. }\end{array}$ \\
\hline R. Rejected & $\begin{array}{l}\text { The title and the abstract } \\
\text { show no relation to the } \\
\text { objectives of the study. }\end{array}$ & $\begin{array}{l}\text { When the article meets the } \\
\text { exclusion criteria. }\end{array}$ & Exclude this reference \\
\hline Q. Questionable & $\begin{array}{l}\text { The article and the abstract } \\
\text { are not clearly related to } \\
\text { the objectives of the study. }\end{array}$ & $\begin{array}{l}\text { When the abstract does not } \\
\text { show clear evidence of } \\
\text { meeting the inclusion criteria, } \\
\text { but seem to be related to } \\
\text { them. }\end{array}$ & $\begin{array}{l}\text { Analyze the full text to } \\
\text { determine whether or not } \\
\text { this reference must be } \\
\text { included in the study. }\end{array}$ \\
\hline I. Interesting & $\begin{array}{l}\text { The article and the abstract } \\
\text { are not explicitly related to } \\
\text { the objectives, but the topic } \\
\text { is interesting for further } \\
\text { research. }\end{array}$ & $\begin{array}{l}\text { When the abstract shows no } \\
\text { evidence of meeting the } \\
\text { inclusion criteria, but the } \\
\text { issue is related to the study, } \\
\text { and could be interesting for } \\
\text { further studies. }\end{array}$ & $\begin{array}{l}\text { Exclude this reference, but } \\
\text { archive it in another folder. }\end{array}$ \\
\hline
\end{tabular}

Table 2. Codification for eligibility stage

Also, we use the snowball procedure to incorporate new references once we finish the methodology commented above.

All the references codified with "Approved" and "Questionable" code were stored in a new folder of Mendeley reference manager. As a result, 48 studies were selected for the inclusion stage.

In the inclusion stage, with the aim of extracting the information of the articles selected in a structured manner, and being able to answer the research questions, we decided to create a table made up of the following items:

- Article: specifying the author, year, and title of the article (i.e. Boselie (2010). High-performance work practices in the health care sector: a Dutch case study.)

- Objectives: a short description about the aim of the study (i.e. "To present an empirical study of the effect of high-performance work practices on commitment and citizenship behavior in the health care sector"'(Boselie, 2010)).

- AMO test? Used for indicating whether or not the study checks either directly or indirectly the AMO framework. That is to say; we answer YES when the study measures the AMOperformance link on the basis of a sample and using statistical methods.

- AMO model: the articles were codified as follows: 
- sum $\mathrm{P}=\mathrm{f}(\mathrm{A}+\mathrm{M}+\mathrm{O})$ : summative model, that is to say, the ability, motivation or opportunity-enhancing practices contribute independently to performance, even when the others practicesare not implemented.

$\circ$ mult $\mathrm{P}=\mathrm{f}(\mathrm{A} \times \mathrm{M} \times \mathrm{O})$ : multiplicative (or interactive) model, which means that ability, motivation, and opportunity practices must be present to ensure performance.

$\circ$ indet $\mathrm{P}=\mathrm{f}(\mathrm{A}, \mathrm{M}, \mathrm{O})$ : We used this code when the study did not explicitly apply either summative or multiplicative model in their statistical analysis.

- N/A: We used this code for studies that did not use any statistical analysis.

- Study: indicating the type of the study (i.e. cross sectional, multilevel analysis, longitudinal, literature review, theoretical model, theory building, interview, survey, questionnaire)

- Year: indicating when the study was conducted or (if this information is not available) the year of publication.

- Country: indicating the country/s where the study was conducted.

- Sample: specifying the type of sampling and sample size used in the study, either at the firm level (i.e. manufacturing or accounting firms)or the individual level (i.e. HR managers, line managers, front-line employees).

- Hypothesis (related to AMO framework): used for identifying (if any) those hypotheses related to the relationship between ability, motivation and/or opportunity practices and organization performance (i.e. "H2a. High scores on perceived HPWPs that enhance abilities (e.g. skills training, general training, coaching) are positively related to high levels of organizational citizenship behavior (OCB)" (Boselie, 2010)).

- Measures of Organization Performance: used for detecting the outcomes used in every study (i.e. productivity, financial performance, turnover intention, employee commitment, efficiency).

- Ability-enhancing practices: human resources practices utilized in the study for boosting employee abilities (A) (i.e. recruitment and selection, training, skill development).

- Motivation-enhancing practices: human resources practices utilized in the study for increasing employee motivation (M) (i.e. incentives, recognition, pay for performance, group bonuses, job security). 
- Opportunity-enhancing practices: human resources practices used in the study for boosting employee opportunities (O) (i.e. quality circles, self-directed work teams, employee involvement activities).

- Control variables: used for identifying the variables used to adjust the relative relationship between the dependent and independent variables, either at the organizational level (i.e. firm age, firm size) or the individual level (i.e. gender, age, educational level, tenure, position level).

- Results: we used this item for indicating whether or not the hypotheses proposed were supported.Also, we used this item for quoting the main conclusion of those studies when no hypothesis related to AMO model was found.

All the 48 studies selected for the inclusion stage were classified according to the items commented above. Therefore, it was necessary to read and analyze the full text of every one of them. The aim was filling out the table in a comprehensive manner, extracting further conclusions without the need to reanalyse those studies again.

\section{Results}

After a careful evaluation of the articles, we consider the review protocol to be valid, since almost every study selected is directly or indirectly related to the AMO framework. Furthermore, as the results were drawn from three different databases, we assume that the sample obtained should adequately cover the current investigations related to the topic. In fact, although Scopus and Web of Science databases only include both the title and the abstract in their automatic search, Google Scholar seeks the chosen terms in the whole article, which should avoid as much as possible the dismissal of relevant studies. Nonetheless, we expect to find out almost every article related to the topic through the snowball strategy performed during the inclusion stage.

All the reviewed articles mention the AMO model in their theoretical framework. Moreover, 33 of them provide a statistical analysis that measures the relationship between ability, motivation, and opportunity-enhancing practices and performance. The other 15 did not conduct any statistical analysis, since they carried out either a literature review (Alagaraja, 2012; Boselie et al., 2005; Drummond \& Stone, 2007; Jiang, Lepak, Hu, et al., 2012; Munteanu, 2014), a theoretical model development (Block \& Pickl, 2014; Hughes, 2007; Minbaeva, 2013), or a case study (Claudia, 2015; Harney \& Jordan, 2008). However, in almost every of them, it was possible to extract measures of operational performance, as well as examples of ability, motivation, and opportunity-enhancing practices. 
As we predicted, not many studies of the sample have the objective of directly validating the AMO framework. In fact, only three of them include that issue as their primary goal (Demortier et al., 2014; Kim, Pathak \& Werner, 2015; Obeidat, Bray \& Mitchell, 2010). As a result, it seems to be a lack of research for explicitly validating the model. Nevertheless, most of the articles indirectly test the model through statistical analysis, which appears to be the common way for analyzing the AMO framework.

Keeping this in mind, we consider that the chosen studies should shed light on our initial research questions, and hence we will now move on to analyze them in detail.

\subsection{What is the AMO framework? When it was first proposed?}

Although we have described the origins of the AMO framework in the introduction section, it is important to emphasize some aspects of the original model for a better understanding of the model and its implications for human resource management. As stated before, the AMO framework was developed by Appelbaum et al. (2000), on the basis of a model previously proposed by Bailey (1993). The aim of the model was to examine the premise that HPWS can help the organization to improve plant performance. To that end, the authors studied the effects of HPWS on plants and employees of three manufacturing industries: steel, apparel and electronic medical instruments (Appelbaum et al., 2000). With the aim of providing a comprehensive picture, they designed a multilevel research, collecting data from workers, managers, and plant performance.

The AMO model of performance (Figure 3) suggested that effective HPWS require three essential components to use effectively employees' discretionary effort: the opportunity to participate, appropriate incentives, and policies for developing employees' abilities and skills. Discretionary behavior refers to the employee's voluntary choice about how to perform their tasks (Boxall \& Purcell, 2003). Positive discretionary behaviors are associated to "going the extra mile". That is to say, wo rking beyond the basic requirements, for instance taking additional tasks (Purcell, Kinnie, Hutchinson, Rayton \& Swart, 2003) cited in Hutchinson (2013). According to AMO model, discretionary effort will positively affect organizational performance. 


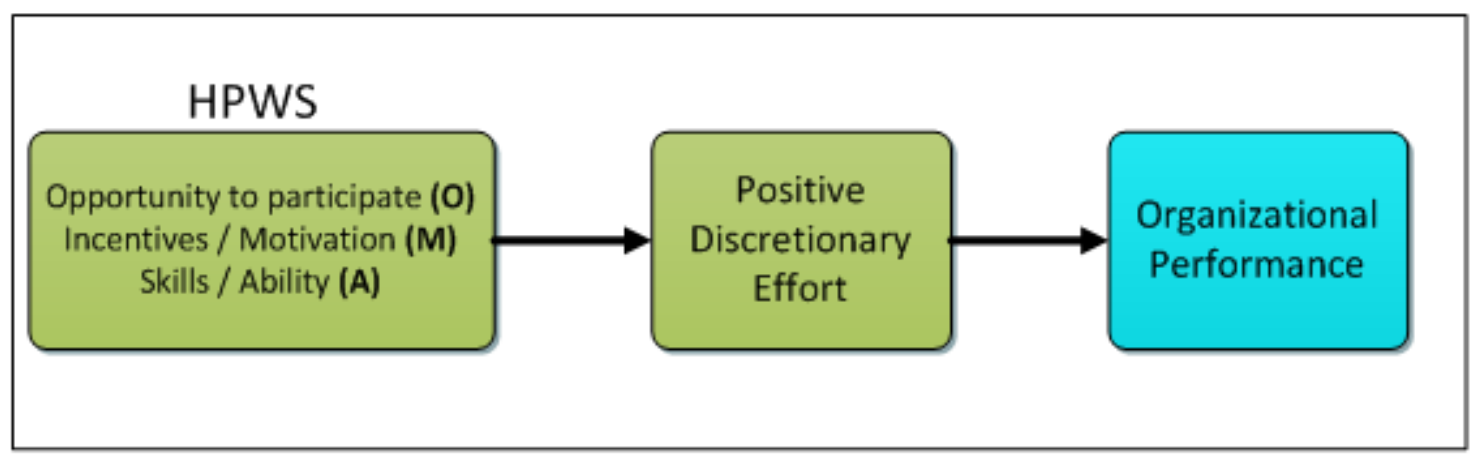

Figure 3. The AMO model of performance adapted from Appelbaum et al.(2000)

It is important to detail the high-performance work system variables originally proposed by the authors in their empirical analysis. In this regard, they develop the following scales and procedures (Table 3):

\begin{tabular}{|c|c|c|}
\hline Scale & Variables & Measures \\
\hline \multirow{4}{*}{$\begin{array}{l}\text { Opportunity to } \\
\text { participate }(\mathrm{O})\end{array}$} & Autonomy in decision making & 1-4 scale: 1 (false) - 4 (true) \\
\hline & Self-directed team membership & Yes / No \\
\hline & Offline team membership & $0=\mathrm{No} / 1=\mathrm{Yes}$ \\
\hline & Communication & 1-5 scale: 1 (never) - 5 (daily) \\
\hline \multirow{4}{*}{ Skills (A) } & Formal training & Yes / No \\
\hline & Informal training & $\begin{array}{c}1-4 \text { scale: } 1 \text { (not at all) - } 4 \text { (to a great } \\
\text { extend) }\end{array}$ \\
\hline & Seniority & - \\
\hline & Education & Low education (1-8) / High school (9-11 \\
\hline \multirow{8}{*}{ Incentives (M) } & Employment security & 1-4 scale: 1 (false) - 4 (true) \\
\hline & Company is competitive & 1-4 scale: 1 (false) - 4 (true) \\
\hline & Company shares information & 1-4 scale: 1 (false) - 4 (true) \\
\hline & Promotion opportunities & $0=$ No $/ 1=$ Yes \\
\hline & Company helps with work-family conflicts & $\begin{array}{c}1-4 \text { scale: } 1 \text { (not at all) - } 4 \text { (to a great } \\
\text { extend) }\end{array}$ \\
\hline & Pay & Weekly earnings \\
\hline & Pay is fair & 1-4 scale: 1 (dissatisfied) - 4 (satisfied) \\
\hline & Pay for performance & $0=\mathrm{No} / 1=\mathrm{Yes}$ \\
\hline
\end{tabular}

Table 3. HPWS scales adapted from Appelbaum et al. (2000)

Finally, it is also interesting to point out the measures of performance used by the authors in their empirical analyses. On the one hand, they examined the effects of HPWS on organizational performance, by using specific performance measures in each industry. As a matter of fact, they conducted a longitudinal study within the steel industry, comparing the monthly delay rates by department. The goal was measuring the effect of HPWS on uptime. In the apparel industry, however, 
the measures of performance were related to product quality, throughput time, capital utilization and space utilization. Finally, in the medical electronic instruments industry, the measures of performance were the following: value added, operating profit, work-in-process inventory, overall productivity, and overall quality. Overall, they demonstrated that HPWS had a positive effect on organization performance in each industry.

On the other hand, the authors also considered the effects of HPWS on workers outcomes. Specifically, they studied five worker outcomes: the extent to which employees trust their managers, the intrinsical job perception, organizational commitment, job satisfaction, and work-related stress. Finally, they also investigated the effect of HPWS on earnings of employees, as well as on productivity growth.

\subsection{Which other HIWP models complement or substitute the AMO framework?}

Along our review protocol, we have identified several theoretical frameworks that either complete the AMO model or propose a different point of view in explaining the linkage between human resources management and performance. Identifying those theoretical frameworks provides valuable information about the assumptions (as well as the selection of specific HR practices and performance outcomes) used by different authors (Boselie et al., 2005). In fact, some authors consider that the AMO framework can be reinforced through other mechanisms for thoroughly explain the HRM-performance linkage (Demortier et al., 2014). Although we identified many theories, it is important to underline three of them, which frequently appear in many of the studies: the contingent framework, the resource-based view model, and the social exchange theory.

The contingent framework suggests that contextual factors are essential for understanding this relationship (Alagaraja, 2012). Thus, HRM must be able to respond effectively to the organization's environment features (Boselie et al., 2005; Delery, 1998; Ruzic, 2015). One example of a contextual factor is the firm's business strategy (i.e. cost leadership or focus differentiation) (Boselie et al., 2005). Contextual factors also involve culture, climate, politics and social interactions. Organization culture includes core values, beliefs and attitudes of organization's members whereas climate refers to employee's interpretations of the work environment (Raidén et al., 2006).

The resource-based view (RBV) model cited in Alagaraja (2012) and (Barney, 1991; Wright \& Boswell., 2001) mentioned in (Boselie et al., 2005; Katou \& Budhwar, 2010) points out that is needed to consider human and social capital held by the organizations. According to this framework, a firm's competitive 
advantage lies in the valuable, rare, difficult to imitate and non-substitutable resources that it possesses (Boselie et al., 2005; Fu et al., 2013; Ruzic, 2015). Therefore, the RBV perspective suggests that HRM policies directly affect the employee motivation, behavior, and abilities, which in turn enhance organizational performance (Boxall and Steeneveld, 1999) cited in Katou and Budhwar (2010). In fact, some authors consider that AMO framework is an extension of RBV model (Ruzic, 2015) because it adds the opportunity dimension to the ability and motivation ones.

Social exchange theory (Blau, 1964) cited in (Boselie, 2010; Demortier et al., 2014; Kroon et al., 2013), emphases on the relationship between the organization and its employees as an exchange of mutual investment. This theory points out that subjective perceptions of the costs and benefits of maintaining this relationship could affect employee performance (Choi, 2014). Einsenberger, Huntington, Hutchison and Sowa (1986), cited in (Choi, 2014; Knies \& Leisink, 2014) extended this theory by explaining that those perceptions could be affected by workplace practices and policies, which may enhance the employee feeling to compensate the organization with appropriate behaviors. The concept used for explaining those subjective perceptions (which in turn explains employee commitment to an organization), is the perceived organizational support (POS) (Knies \& Leisink, 2014). Highperformance work practices are expected to send positive messages to employees, increasing their willingness to perform better in their job (Boselie, 2010; Godard, 2000). These positive messages are also known as signaling effect (Bowen \& Ostroff, 2004; Ehrnrooth \& Björkman, 2012), which suggest that HRM systems send messages to employees who, in turn, align their efforts toward the organization goals. As a matter of fact, the perceived availability of flexibility practices will enhance employee motivation and performance. The reason is that they will observe positive signals from an organization that cares about their work-life balance (Bal \& De Lange, 2015).

Besides the theories mentioned above, it is appropriate to note, if even briefly, the following theoretical frameworks identified in our study:

- Generation theory (Twenge, Campbell \& Freeman, 2010) cited in Bal and De Lange (2015), predicts that younger employees value the flexibility at work more than older workers. However, older workers may use flexibility to counteract the consequences of age-related losses in capabilities, predicted by the lifespan theory of selection, optimization and compensation (Baltes, 1997) cited in Bal and De Lange (2015). Thus, opportunity-enhancing practices related to flexibility may be appropriate for younger and older workers for different reasons. 
- Organizational ethical climates (Victor \& Cullen, 1988) cited in Guerci, Radaelli, Siletti, Cirella and Rami Shani (2015) deals with the shared perceptions of what are correct behaviors, feelings, and attitudes within an organization. According to this theory, the organization climate can be egoistic (employees self-interest guide their behavior), benevolent (well-being of others guide employee's behavior) or principled (employee behavior is guided by either informal or formal norms and rules) (Guerci et al., 2015). Consequently, organization climate may affect the HRM activities to a great extent, by influencing employee commitment and satisfaction.

- The people-performance framework (Purcell et al., 2003) cited in Harney and Jordan (2008) is a comprehensive model that aims to "unlocking the black box" of HRM-performance linkages. This model consists of four keypillars. Pillar 1 is related to HRM practices, and the authors suggest that the HR policy chosen by an organization must be adapted to its organizational context (in line with contingency theory). Pillar 2 takes place inside the "black box", and includes the role of both line managers and employees on applying and perceiving respectively the HRM policies and practices. The authors integrate the AMO framework by suggesting that firm performance is a function of line managers ability, motivation and opportunity to implement those practices. Pillar 3 deals with managerial style as an important factor to consider, because employee's perceptions may vary significantly depending on the line manager approach. In fact, people is likely to commit more to individuals rather to the overall organization (Becker, 1992) cited in Harney and Jordan (2008). Finally, Pillar 4 takes into account intermediary measures of people-performance, such as commitment, motivation, and job satisfaction. These measures are necessary for understanding the HRM-performance linkage.

- Resource-poverty perspective (Welsh and White 1981) cited in Kroon et al. (2013), predicts that availability of financial resources and time is related to the organization size. That is to say; small companies have fewer resources to implement HRM practices than larger firms.

- Different behavioral theories, drawn from disciplines such as Psychology or organizational behavior. Examples of these approaches are expectancy theory (Vroom, 1964), the theory of planned behavior or theory of values and attitudes (Triandis, 1980), all of them quoted in Hughes (2007). 


\subsection{What investigations have been conducted to validate the model?}

As we said before, few studies drawn from our systematic review directly test the AMO framework. Taking into account the searching strategy conducted and the results obtained, it would be surprising the existence of many more investigations testing that issue. Moreover, a quick revision (both title and abstract) of the studies extracted through the snowball procedure seem to support this view. Therefore, it appears to be a lack of research aiming to validate the model directly. However, most of the articles reviewed indirectly test the model by using statistical analysis in which they estimate the average correlation among HR practices in bundles by using a Cronbach's alpha. Those studies provide examples of HR practices as well as different measures of performance. Also, the studies that do not provide a statistical analysis, they nonetheless give an idea of how authors understood the HR practices-performance linkage.

Concerning the country in which the investigation is performed, we expected to find out studies conducted mainly in north-American and European countries, particularly in Anglo-Saxon countries such as the United States and the United Kingdom. Surprisingly, our systematic review contains studies from more than 20 countries on almost every continent. We consider that this information is remarkable because it might reduce bias caused by the country-of-origin factor (e.g. labor regulations). Many of the studies were conducted in European countries (27), distributed as follows: UK (7), The Netherlands (6), Denmark (3), Ireland (2), Romania (1), Luxemburg (1), Sweden (1), Belgium (1), Italy (1), Greece (1), Croatia (1), and Germany (1). However, other studies were conducted within the Asian context (12) (China-3, Korea-4, India-1, Taiwan-1, Hong Kong-1, Jordania-1, and Turkey-1). We also found studies performed in the United States (5), New Zealand (1), Uruguay (1) and Australia (1). Finally, some studies collect data from several countries, for instance (Japan, Brazil, China, Mexico, USA, Spain, India, UK, South Africa, Netherlands, Botswana) (Bal \& De Lange, 2015), and (Italy, Germany, UK, Poland, Spain, France) (Guerci et al., 2015).

With regard to the data-gathering tools, our review protocol shows that information is usually collected through surveys or questionnaires. Questionnaires include a planned set of question to be submitted to many persons. Questionnaires and surveys are commonly used in studies with a large number of respondents because they present several advantages. First, they involve lower cost than interviews, because there is no need to train and send interviewers to the workplace. Also, the uniformity of questions provides data that is easy to gather, process and extract conclusions from it. However, these data-gathering tools also present some disadvantages. First, it is hard to assess respondent's motivation, which can affect the validity of the response. Moreover, it is difficult to control the returning rate, 
which may represent biased samples. The most common type of questionnaire along our review protocol is to prepare a set of questions related to the three dimensions of the AMO model, aiming to find out the employee or manager perceptions or assumptions concerning those practices. The HR practices are usually measured by using different scales, which assess whether these practices are present or not. As a matter of fact, the item "the organization evaluates my job performance based on objective and measurable results" can be measured with a 1-7 scale ("1 = absolutely disagree"; "7 = totally agree") (Ming, Ganli \& Fulei, 2014).

However, we have also found some investigations using interviews (e.g. (Bello-Pintado, 2015; Claudia, 2015; Sterling \& Boxall, 2013)). That is to say; a face-to-face methodology for obtaining reliable measures in the form of verbal responses. The advantages of interviews are the following: first, they enable the interviewer to clarify questions if needed. Also, allows the informants to clarify in greater detail the answers. Finally, it allows the interviewers to observe verbal and non-verbal behaviors. Along our review protocol, interviews are commonly used in studies with few respondents, especially for collecting information from managers. As a matter of fact, Bello-Pintado (2015), conducted a set of interviews with plant managers of Uruguayan manufacturing firms. Also, other authors used this methodology to collect data from HR managers (Ruzic, 2015), or even front-line workers (Sterling \& Boxall, 2013).

According to our searching protocol, most empirical works are based on cross-sectional data. Those studies involve the use of regression analyses at a given point in time, with the aim of determining the causal effects of HR practices (independent variable) and performance (dependent variable). Concerning the sample survey, it is typically collected at different organizational levels to obtain a variety of perspective (multilevel analysis). The aim is minimizing bias caused by factors such as only consider the manager's voice. Also, many of the studies gather data across different industry sectors, enabling generalization of findings (Alagaraja, 2012). As a matter of fact, Kroon et al. (2013) conducted an investigation among Dutch local small firms collecting data from both the service sector and the construction industry. In the same vein, Obeidat et al. (2010) gathered data from Jordanian manufacturing and financial sectors. Also, Innocenti et al. (2011) took into consideration a diverse sample, including Italian companies from distribution, marketing, consultancy and production. Moreover, Choi (2014) included in their investigation a survey sample of 454 South Korean firms, representing manufacturing, non-financial services and financial services industries.

The use of cross-sectional studies is useful for determining correlations among independent and dependent variables. However, some authors have criticized that such studies are not able to establish 
causal relationships (Knies \& Leisink, 2014; Shih, Chiang \& Hsu, 2007; Wall \& Wood, 2005). In fact, it might be important to measure the effect of high-performance work systems after a certain time span since its implementation. Nevertheless, other authors point out that this fact must not prevent companies from investing in HPWS (Shih et al., 2007). Longitudinal studies involve a survey of the same population over a period of time and are mainly conducted to detect changes in attitudes, feelings or results. That is to say; those studies might be able to determine causality. However, the use of longitudinal studies is a costly and complicated task, because it means to measure more times on equal terms. For this reason, some authors point out that fewer longitudinal studies investigated the relationship between HRM and performance (Alagaraja, 2012). In fact, we only found six articles within our review protocol conducting entirely or partially a longitudinal research (Bal \& De Lange, 2015; Block \& Pickl, 2014; Choi \& Yoon, 2015; Demortier et al., 2014; Knies \& Leisink, 2014; Shih et al., 2007).

Another concern detected in our results is the large variety of methodologies through investigations. That is to say, different data produce different results(Alagaraja, 2012), and the large variety of HR practices and measures of performance (e.g. productivity, employee commitment) used through investigations make it difficult to state firm conclusions. Moreover, scholars have used a wide variety of control variables, ranging from industry-level controls (e.g. technology, market conditions), to organization-level controls (e.g. size, firm, economic activity), and to individual level control (e.g. age, gender, the level of education). This lack of consensus is evident throughout the articles reviewed and, therefore, it is hard to identify how HR practices should be measured (e.g. index, scales) (Harney \& Jordan, 2008)

\subsection{What HIW practices have been used to analyze the AMO framework?}

As we pointed out in the introduction, the variety of practices across investigations makes it difficult to state conclusions about which bundle of practices (if any) better fit for exploring the HRM practicesperformance linkage. In this regard, it is essential to underline the existence of two opposite points of view. On the one hand, the universalist perspective states that effective contribution of an HRM system to one organization can be spread to other organizations, without taking into account the particular context (Huselid, 1995; Ruzic, 2015; Schimansky, 2014). Thus, this approach considers that some HRM activities are always better than others (Ruzic, 2015). In fact, some authors point out the existence of a "core high-performance work systems", which aim to provide employees with the proper abilities to 
perform, the means to do their jobs, and the motivation needed (Shih et al., 2007). Practices related to those systems are selection and training programs, information sharing and worker involvement, and incentive arrangements that provide motivation (Marín-García \& Conci, 2013; Shih et al., 2007). On the other hand, the contingency approach emphasizes that optimal HRM systems must be adapted to particular circumstances and be consistent within the organization (Ehrnrooth \& Björkman, 2012; Ruzic, 2015). As a matter of fact, some authors point out that industries require different skills and knowledge (Schimansky, 2014). Moreover, some scholars state that choosing the right combination of practices is crucial to better performance, and similar bundles may be negatively related to positive outcomes depending on the context (Godard, 2001; Shih et al., 2007).

In any case, there are several HRM practices that commonly appear in many investigations (PerellóMarin \& Ribes-Giner, 2014). The four most frequently considered in many "bundles" are recruitment and selection, training and development, reward schemes, and performance management (Boselie et al., 2005). Some authors suggest the appropriateness of conceptualizing HRM systems into the AMO dimensions. That is to say, grouping them as ability, motivation or opportunity-enhancing practices (Claudia, 2015; Jiang, Lepak, Hu, et al., 2012). In this sense, Appelbaum et al. (2000) offered several examples of HR practices for ability (e.g. formal and informal training), motivation (e.g. job security, promotion opportunities), and opportunity to participate (e.g. autonomy, communication) (Claudia, 2015).

In light of this, we thought it opportune to analyze the HRM practices collected across our review protocol according to the three AMO dimensions (Table 4), as we explain below.

Ability can be defined as an acquired or natural capacity that enables an individual to perform a particular task successfully (Kim et al., 2015). Moreover, ability refers to human attributes (skills, experience, attitudes, prior related knowledge) that are relevant for the accomplishment of those tasks (Boon, Belschak, Hartog \& Pijnenburg, 2014; Minbaeva, 2013). In HRM context, ability refers to the set of practices designed for ensuring that the employees have the resources needed for performing their tasks (Sarikwal \& Gupta, 2013). Hence, those practices focus on increasing the knowledge, skills and abilities (KSA) at both individual and collective levels (Demortier et al., 2014; Subramony, 2009).

According to our searching protocol, many authors agree that examples of ability-enhancing practices are primarily related to training and career, and recruitment and selection. Training and development practices improve the chances of developing new abilities (Bos-Nehles et al., 2013; Schimansky, 2014), as well as to understand problems and discover new opportunities, whereas recruitment and selection 
deals with attracting and choosing individuals who conform to the profile and the organization (Schimansky, 2014).

\begin{tabular}{|c|c|c|}
\hline $\begin{array}{c}\text { AMO } \\
\text { Dimension }\end{array}$ & HR practices & Research Articles \\
\hline \multirow[t]{3}{*}{ Ability (A) } & $\begin{array}{l}\text { Training and } \\
\text { Development }\end{array}$ & $\begin{array}{l}\text { (An, 2009; Armstrong, Flood, Guthrie, Liu, MacCurtain \& Mkamwa., } \\
\text { 2010; Bainbridge, 2015; Bello-Pintado, 2015; Block \& Pickl, 2014; Boon et } \\
\text { al., 2014; Boselie et al., 2005; Boselie, 2010; Choi \& Yoon, 2015; Choi, } \\
\text { 2014; Claudia, 2015; Demortier et al., 2014; Drummond \& Stone, 2007; } \\
\text { Ehrnrooth \& Björkman, 2012; Fu et al., 2013; Ganli, Long, \& Ming, 2014; } \\
\text { Gould-Williams \& Gatenby, 2010; Guerci et al., 2015; Harney \& Jordan, } \\
\text { 2008; Innocenti et al., 2011; Jiang, Lepak, Hu, et al., 2012; Katou \& } \\
\text { Budhwar, 2010; Knies \& Leisink, 2014; Kroon et al., 2013; Ming et al., } \\
\text { 2014; Munteanu, 2014; Obeidat et al., 2010; Raidén et al., 2006; Ramsay, } \\
\text { Scholarios \& Harley, 2000; Renwick, Redman \& Maguire, 2012; Ruzic, } \\
\text { 2015; Sarikwal \& Gupta, 2013; Schimansky, 2014; Shih et al., 2007; Shin, } \\
\text { Jeong \& Bae, 2016; Sterling \& Boxall, 2013; Tuuli \& Rowlinson, 2009; } \\
\text { Vermeeren, Kuipers \& Steijn, 2014; Wood et al., 2015) }\end{array}$ \\
\hline & $\begin{array}{l}\text { Recruitment and } \\
\text { Selection }\end{array}$ & $\begin{array}{l}\text { (Armstrong et al., 2010; Bello-Pintado, 2015; Boselie et al., 2005; } \\
\text { Ehrnrooth \& Björkman, 2012; Fu et al., 2013; Ganli et al., 2014; Guerci et } \\
\text { al., 2015; Harney \& Jordan, 2008; Jiang, Lepak, Hu, et al., 2012; Katou \& } \\
\text { Budhwar, 2010; Ming et al., 2014; Obeidat et al., 2010; Raidén et al., 2006; } \\
\text { Ramsay et al., 2000; Renwick et al., 2012; Ruzic, 2015; Sarikwal \& Gupta, } \\
\text { 2013; Schimansky, 2014; Shih et al., 2007; Vermeeren et al., 2014) }\end{array}$ \\
\hline & $\begin{array}{l}\text { Performance } \\
\text { Evaluation }\end{array}$ & $\begin{array}{l}\text { (An, 2009; Boselie et al., 2005; Choi, 2014; Claudia, 2015; Drummond \& } \\
\text { Stone, 2007; Ehrnrooth \& Björkman, 2012; Fu et al., 2013; Innocenti et al., } \\
\text { 2011; Katou \& Budhwar, 2010; Knies \& Leisink, 2014; Sarikwal \& Gupta, } \\
\text { 2013; Wood et al., 2015) }\end{array}$ \\
\hline
\end{tabular}

Table 4. Ability-enhancing practices retrieved from the Review protocol

Motivation can be defined as "the degree to which an individual wants and chooses to engage in certain specified behaviors" (Kim et al., 2015). Motivation can be either extrinsic or intrinsic ( Marín-García \& De Miguel, 2001; Minbaeva, 2013; Sarikwal \& Gupta, 2013). External factors are related to incentives such as economic rewards and usually leads to focus on short-term gains, whereas intrinsic factors emanate from individual's interests and values, for instance when a person find a job satisfying and pleasant (Minbaeva, 2013; Schimansky, 2014). Intrinsic motivation is usually linked with employee's long-term commitment (Schimansky, 2014). However, some authors point out that, sometimes, a lack of extrinsic factors can affect the intrinsic motivation (Bos-Nehles et al., 2013). Also, motivation can also be affected by employee's ability, because employees with lack of skill may become demotivated if they consider that the task is too difficult (Bos-Nehles et al., 2013). In HRM context, motivationenhancing practices foster employee's efforts for accomplishing the objectives and deliver high levels of performance. Therefore, motivation bundle comprises practices such as performance appraisal usually linked to financial or non-financial incentives (Demortier et al., 2014). 
According to our review protocol, the most common motivation-enhancing practices are related to performance appraisal and extrinsic incentives (Table 5). As a matter of fact, pay for performance is used in many investigations, both at the individual or at the group level. However, we also found in many studies non-economic forms of motivation, such as recognition, job security, internal promotion (or career development), social activities, and work-life balance opportunities. In contrast, we did not find many examples practices focusing on intrinsic motivation. Some of the few examples we found are motivation to learn, personal or team satisfaction, willingness to perform, corporate sense, and collaborative climate.

\begin{tabular}{|c|c|c|}
\hline $\begin{array}{c}\text { AMO } \\
\text { Dimension }\end{array}$ & HR practices & Research Articles \\
\hline \multirow{9}{*}{$\begin{array}{l}\text { Motivation (M) } \\
\quad \text { (Extrinsic) }\end{array}$} & Performance Appraisal & $\begin{array}{l}\text { (Armstrong et al., 2010; Bello-Pintado, 2015; Boon et al., 2014; Gould- } \\
\text { Williams \& Gatenby, 2010; Jiang, Lepak, Hu, et al., 2012; Ming et al., } \\
\text { 2014; Obeidat et al., 2010; Ramsay et al., 2000; Vermeeren, 2010) }\end{array}$ \\
\hline & $\begin{array}{l}\text { Extrinsic } \\
\text { Incentives }\end{array}$ & $\begin{array}{l}\text { (An, 2009; Bainbridge, 2015; Block \& Pickl, 2014; Boon et al., 2014; } \\
\text { Ehrnrooth \& Björkman, 2012; Innocenti et al., 2011; Jiang, Lepak, Hu, } \\
\text { et al., 2012; Katou \& Budhwar, 2010) }\end{array}$ \\
\hline & $\begin{array}{l}\text { Pay for Performance } \\
\text { (Individual) }\end{array}$ & $\begin{array}{l}\text { (Choi, 2014; Demortier et al., 2014; Fu et al., 2013; Ganli et al., 2014; } \\
\text { Ramsay et al., 2000; Sarikwal \& Gupta, 2013; Wood et al., 2015) }\end{array}$ \\
\hline & $\begin{array}{l}\text { Pay for Performance } \\
\text { (Group level) }\end{array}$ & $\begin{array}{l}\text { (Armstrong et al., 2010; Bello-Pintado, 2015; Demortier et al., 2014; } \\
\text { Ganli et al., 2014; Ming et al., 2014; Wood et al., 2015) }\end{array}$ \\
\hline & Recognition & $\begin{array}{l}\text { (Bainbridge, 2015; Block \& Pickl, 2014; Claudia, 2015; Innocenti et al., } \\
\text { 2011) }\end{array}$ \\
\hline & Job Security & $\begin{array}{l}\text { (Bello-Pintado, 2015; Boselie et al., 2005; Jiang, Lepak, Hu, et al., 2012; } \\
\text { Raidén et al., 2006; Sarikwal \& Gupta, 2013) }\end{array}$ \\
\hline & $\begin{array}{l}\text { Internal } \\
\text { Promotion }\end{array}$ & $\begin{array}{l}\text { (Bello-Pintado, 2015; Boselie et al., 2005; Ganli et al., 2014; Katou \& } \\
\text { Budhwar, 2010; Kroon et al., 2013; Raidén et al., 2006; Sarikwal \& } \\
\text { Gupta, 2013; Wood et al., 2015) }\end{array}$ \\
\hline & Social Activities & (Boselie et al., 2005; Harney \& Jordan, 2008) \\
\hline & $\begin{array}{l}\text { Work-life Balance } \\
\text { Opportunities }\end{array}$ & $\begin{array}{l}\text { (Boselie et al., 2005; Knies \& Leisink, 2014; Munteanu, 2014; Raidén et } \\
\text { al., 2006; Sarikwal \& Gupta, 2013; Wood et al., 2015). }\end{array}$ \\
\hline \multirow{5}{*}{$\begin{array}{l}\text { Motivation (M) } \\
\quad \text { (Intrinsic) }\end{array}$} & Motivation to Learn & (Sterling \& Boxall, 2013) \\
\hline & $\begin{array}{l}\text { Personal or Team } \\
\text { Satisfaction }\end{array}$ & $\begin{array}{l}\text { (Block \& Pickl, 2014; Drummond \& Stone, 2007; Harney \& Jordan, } \\
\text { 2008; Tuuli \& Rowlinson, 2009) }\end{array}$ \\
\hline & Willingness to Perform & (Bos-Nehles et al., 2013) \\
\hline & Corporate Sense & (Demortier et al., 2014) \\
\hline & Collaborative Climate & (Kim et al., 2015) \\
\hline
\end{tabular}

Table 5. Motivation-enhancing practices retrieved from the Review protocol

Opportunity can be defined as a set of circumstances that makes it possible to do something. Employees' opportunity to participate has several dimensions, such as involvement in the decisionmaking process, knowledge sharing, horizontal communication and job enrichment (Schimansky, 2014). Organizations willing to foster participation should provide the means to improve those dimensions, by decreasing the distance between employees and management. That is to say, in this context opportunity 
is linked to employee involvement in the decision-making process (Appelbaum et al., 2000). Hence, firms must provide opportunities for dialogue across organizational hierarchies, creating systems for capturing and sharing knowledge within the organization (Minbaeva, 2013; Senge, Ross, Smith, Roberts \& Kleiner, 1995). Also, the decision-making process should be decentralized and, consequently, employees will enjoy a higher level of autonomy for performing their tasks ( Marín-García \& De Miguel, 2001; Sarikwal \& Gupta, 2013). In HRM context, opportunity-enhancing practices are designed for delegating the decision-making authority and fostering employee voice (Demortier et al., 2014). Thus, participation is seen as an opportunity for employees to be involved (Marín-García \& De Miguel, 2001; Schimansky, 2014). Likewise, based on organizational support theory (Boon et al., 2014), signals that the organization invests in supportive activities may lead to improving the employee sense of belongingness and reducing stress, absence and turnover rates (Boon et al., 2014).

According to our searching protocol, the opportunity-enhancing practices may be grouped in four principal bundles: employee-involvement practices, knowledge-sharing practices, job design practices and autonomy-enhancing practices (Table 6).

Employee-involvement practices include quality circles, self-directed work teams, problem-solving teams, team working, and those practices fostering flat hierarchies and involvement in the decisionmaking process.

The aim of knowledge-sharing practices is providing enough information about important issues within the organization (performance, financial, operating or strategic information). Also, those practices also aim to guarantee communication between employees and management. According to our results, many authors agree that both information sharing and communication are essential for improving the opportunity-enhancing dimension. In addition, many authors also consider as important those practices designed to foster employee voice, such as suggestions systems, complaint systems or surveys in place.

Job design practices include appropriate job description (practices, procedures and workplace design), support from HR professionals, job rotation, level of internationalization and providing favorable work conditions.

Finally, autonomy-enhancing practices are designed to decentralize the decision-making process and provide employees autonomy in their workplace. Also, those practices are also related to both irregular and regular flexibility. 


\begin{tabular}{|c|c|c|}
\hline $\begin{array}{c}\text { AMO } \\
\text { Dimension }\end{array}$ & HR practices & Research Articles \\
\hline \multirow{5}{*}{$\begin{array}{l}\text { Opportunity }(\mathrm{O}) \\
\text { (employee involvement) }\end{array}$} & Quality Circles & $\begin{array}{l}\text { (Armstrong et al., 2010; Choi, 2014; Fu et al., 2013; Ramsay et al., } \\
2000)\end{array}$ \\
\hline & $\begin{array}{l}\text { Self-directed Work } \\
\text { Teams }\end{array}$ & $\begin{array}{l}\text { (An, 2009; Armstrong et al., 2010; Fu et al., 2013; Ramsay et al., } \\
\text { 2000; Sterling \& Boxall, 2013) }\end{array}$ \\
\hline & Problem-Solving Teams & $\begin{array}{l}\text { (Armstrong et al., 2010; Choi, 2014; Drummond \& Stone, 2007; } \\
\text { Fu et al., 2013; Ramsay et al., 2000; Wood et al., 2015) }\end{array}$ \\
\hline & Team Working & $\begin{array}{l}\text { (Boon et al., 2014; Boselie et al., 2005; Drummond \& Stone, 2007; } \\
\text { Gould-Williams \& Gatenby, 2010; Harney \& Jordan, 2008; Jiang, } \\
\text { Lepak, Hu, et al., 2012; Kroon et al., 2013; Munteanu, 2014; } \\
\text { Raidén et al., 2006; Sarikwal \& Gupta, 2013) }\end{array}$ \\
\hline & $\begin{array}{l}\text { Involvement in the } \\
\text { Decision making Process }\end{array}$ & $\begin{array}{l}\text { Boselie et al., 2005; Boselie, 2010; Ehrnrooth \& Björkman, 2012; } \\
\text { Gould-Williams \& Gatenby, 2010; Guerci et al., 2015; Harney \& } \\
\text { Jordan, 2008; Jiang, Lepak, Hu, et al., 2012; Katou \& Budhwar, } \\
\text { 2010; Munteanu, 2014; Raidén et al., 2006; Renwick et al., 2012; } \\
\text { Sarikwal \& Gupta, 2013) }\end{array}$ \\
\hline \multirow[t]{2}{*}{$\begin{array}{c}\text { Opportunity (O) } \\
\text { (Knowledge - Sharing) }\end{array}$} & $\begin{array}{l}\text { Information Sharing and } \\
\text { Communication }\end{array}$ & $\begin{array}{l}\text { (An, 2009; Armstrong et al., 2010; Bello-Pintado, 2015; Block \& } \\
\text { Pickl, 2014; Boselie et al., 2005; Choi, 2014; Drummond \& Stone, } \\
\text { 2007; Ehrnrooth \& Björkman, 2012; Fu et al., 2013; Harney \& } \\
\text { Jordan, 2008; Jiang, Lepak, Hu, et al., 2012; Katou \& Budhwar, } \\
\text { 2010; Ming et al., 2014; Raidén et al., 2006; Shih et al., 2007; Shin } \\
\text { et al., 2016) }\end{array}$ \\
\hline & $\begin{array}{l}\text { Suggestions Systems, } \\
\text { Complaint Systems or } \\
\text { Surveys in Place }\end{array}$ & $\begin{array}{l}\text { (Boselie et al., 2005; Choi, 2014; Ganli et al., 2014; Guerci et al., } \\
\text { 2015; Innocenti et al., 2011; Jiang, Lepak, Hu, et al., 2012; Ramsay } \\
\text { et al., 2000; Wood et al., 2015) }\end{array}$ \\
\hline \multirow{5}{*}{$\begin{array}{l}\text { Opportunity (O) } \\
\text { (Job Design) }\end{array}$} & Job Description & $\begin{array}{l}\text { (Bainbridge, 2015; Block \& Pickl, 2014; Boon et al., 2014; Boselie } \\
\text { et al., 2005; Bos-Nehles et al., 2013; Fu et al., 2013; Guerci et al., } \\
\text { 2015; Harney \& Jordan, 2008; Innocenti et al., 2011; Jiang, Lepak, } \\
\text { Hu, et al., 2012; Katou \& Budhwar, 2010; Knies \& Leisink, 2014; } \\
\text { Shin et al., 2016), }\end{array}$ \\
\hline & $\begin{array}{l}\text { Support from HR } \\
\text { Professionals }\end{array}$ & $\begin{array}{l}\text { (Bos-Nehles et al., 2013; Choi \& Yoon, 2015; Renwick et al., 2012; } \\
\text { Schimansky, 2014) }\end{array}$ \\
\hline & Job Rotation & $\begin{array}{l}\text { (Boselie, 2010; Choi, 2014; Katou \& Budhwar, 2010; Shin et al., } \\
\text { 2016) }\end{array}$ \\
\hline & $\begin{array}{l}\text { Level of } \\
\text { Internationalization }\end{array}$ & (Kim et al., 2015) \\
\hline & $\begin{array}{l}\text { Favorable Work } \\
\text { Conditions }\end{array}$ & (Block \& Pickl, 2014) \\
\hline \multirow[t]{2}{*}{$\begin{array}{l}\text { Opportunity }(\mathrm{O}) \\
\text { (Autonomy-enhancing) }\end{array}$} & Autonomy & $\begin{array}{l}\text { (Bello-Pintado, 2015; Boselie et al., 2005; Boselie, 2010; } \\
\text { Drummond \& Stone, 2007; Ehrnrooth \& Björkman, 2012; Knies } \\
\text { \& Leisink, 2014; Kroon et al., 2013; Ming et al., 2014; Sarikwal \& } \\
\text { Gupta, 2013; Vermeeren, 2010) }\end{array}$ \\
\hline & $\begin{array}{l}\text { Irregular and Regular } \\
\text { Flexibility }\end{array}$ & $\begin{array}{l}\text { (Bal \& De Lange, 2015; Claudia, 2015; Drummond \& Stone, 2007; } \\
\text { Wood et al., 2015) }\end{array}$ \\
\hline
\end{tabular}

Table 6. Opportunity-enhancing practices retrieved from the Review protocol

\subsection{How have been measured the model effectiveness in AMO research?}

Similarly to the previous point, there is a broad range of performance measures across investigations. Hence, organizational performance becomes a very diffuse term, as it can be conceived from different approaches (An, 2009). Indeed, there is no consensus about which criteria should be used to assess HRM effectiveness (Bos-Nehles et al., 2013). Consequently, some authors argue that the term 
"outcomes" reflect better the wide range of dependent variables used across investigations (Boselie et al., 2005; Guest, 1997).

Some authors point out that measures of performance should be related to financial outcomes (e.g. profits, market share, sales growth), because they are the best indicators of organizational success (Boselie et al., 2005; Ichniowski, Kochan, Levine, Olson \& Strauss, 1996). However, other scholars consider that the use of more "proximal" outcome indicators (such as organizational and HR-related outcomes) is more appropriate for engaging workforce (Boselie et al., 2005; Claudia, 2015; Guest, 1997). As a result, some investigations have measured performance through organizational outcomes, such as productivity, product or service quality, or efficiency. The main problem concerning those outcomes is the difficulty in standardizing the measures of them (Boselie et al., 2005).

Also, other studies have taken into account HR-related outcomes, such as employee commitment, job satisfaction, creativity intention to quit, trust in management, and absenteeism. They argue that employees are often the most suitable people to make decisions concerning their work. Therefore, it is important to measure the effects of HPWS on these employee outcomes (Drummond \& Stone, 2007). In this vein, work performance theory defines performance as individual behavior associated with the accomplishment of expected role requirements (Bos-Nehles et al., 2013).

Similarly, other investigations consider that HR-related outcomes are in fact mediating variables between HRM and operational performance (Katou \& Budhwar, 2010; Lepak et al., 2006; Paauwe, 2004; Ramsay et al., 2000). It is important to underline that employee performance usually depends on the perception of the HRM content. That is to say; it is important to ensure that practices are perceived as meaningful for achieving personal and organization goals (Ehrnrooth \& Björkman, 2012). In this sense, it is essential to guarantee that practices are consistent with the business strategy. In such a way, practices are more likely to engage employees toward the organization objectives. In relation to HRrelated outcomes, it is interesting to note the concept "Organization Citizenship Behavior" (OCB). This term is defined as individual behavior that is discretionary, that is to say, goes beyond the basic requirements, without being explicitly recognized by the formal reward systems (Fields, 2002; Sarikwal \& Gupta, 2013).

Concerning the efficacy of HPWS, many empirical investigations have shown a positive association between the adoption of high-performance work practices and different indicators of organization outcomes (Kaufman, 2015; Obeidat et al., 2010; Juárez-Tarrega, 2011; Luján-García, Garrido-Vega \& Escobar-Pérez, 2015). However, there is no consensus among scholars and, indeed, some of them have 
suggested that such positive effect remains unclear (Claudia, 2015). In this sense, it is important to point out that most of the investigations have focused on organizational-level analysis, while little attention has been paid to the individual employee (Boselie, 2010; Guest, 1999).

According to our review protocol, the measures of performance may be grouped in three principal bundles: Financial outcomes, operational outcomes, and HR outcomes (Table 7).

\begin{tabular}{|c|c|c|}
\hline Bundle & Measures & Research Articles \\
\hline \multirow{4}{*}{$\begin{array}{l}\text { Financial } \\
\text { Outcomes }\end{array}$} & Market Share & $\begin{array}{l}\text { (Alagaraja, 2012; Fu et al., 2013; Jiang, Lepak, Han, et al., 2012; Munteanu, } \\
\text { 2014) }\end{array}$ \\
\hline & Profitability & $\begin{array}{l}\text { (Alagaraja, 2012; Boselie et al., 2005; Fu et al., 2013; Kaufman, 2015; Kim } \\
\text { et al., 2015; Obeidat et al., 2010; Ramsay et al., 2000; Shih et al., 2007) }\end{array}$ \\
\hline & Return on Assets (ROA) & $\begin{array}{l}\text { (Alagaraja, 2012; Choi \& Yoon, 2015; Choi, 2014; Jiang, Lepak, Hu, et al., } \\
\text { 2012; Obeidat et al., 2010; Ruzic, 2015) }\end{array}$ \\
\hline & Sales Growth & $\begin{array}{l}\text { (Alagaraja, 2012; Drummond \& Stone, 2007; Fu et al., 2013; Jiang, Lepak, } \\
\text { Hu, et al., 2012; Kaufman, 2015; Obeidat et al., 2010) }\end{array}$ \\
\hline \multirow{5}{*}{$\begin{array}{l}\text { Operational } \\
\text { Outcomes }\end{array}$} & Job Performance & $\begin{array}{l}\text { (Bal \& De Lange, 2015; Choi \& Yoon, 2015; Demortier et al., 2014; } \\
\text { Ehrnrooth \& Björkman, 2012; Gould-Williams \& Gatenby, 2010; Jiang, } \\
\text { Lepak, Hu, et al., 2012) }\end{array}$ \\
\hline & Productivity/ Efficiency & $\begin{array}{l}\text { (Alagaraja, 2012; Armstrong et al., 2010; Bello-Pintado, 2015; Boselie et al., } \\
\text { 2005; Jiang, Lepak, Hu, et al., 2012; Katou \& Budhwar, 2010; Kim et al., } \\
\text { 2015; Obeidat et al., 2010; Raidén et al., 2006; Ramsay et al., 2000; } \\
\text { Vermeeren et al., 2014) }\end{array}$ \\
\hline & Product/ Service Quality & $\begin{array}{l}\text { (Alagaraja, 2012; Bello-Pintado, 2015; Boselie et al., 2005; Fu et al., 2013; } \\
\text { Jiang, Lepak, Hu, et al., 2012; Katou \& Budhwar, 2010; Ramsay et al., 2000; } \\
\text { Sterling \& Boxall, 2013) }\end{array}$ \\
\hline & HRM effectiveness & $\begin{array}{l}\text { (Bainbridge, 2015; Bos-Nehles et al., 2013; Gilbert, De Winne \& Sels, 2015; } \\
\text { Harney \& Jordan, 2008; Shih et al., 2007) }\end{array}$ \\
\hline & Customer Satisfaction & (Alagaraja, 2012; Hughes, 2007; Katou \& Budhwar, 2010) \\
\hline \multirow{10}{*}{$\begin{array}{c}\text { HR } \\
\text { Outcomes }\end{array}$} & Turnover Intention & $\begin{array}{l}\text { (Alagaraja, 2012; Armstrong et al., 2010; Boselie et al., 2005; Gould- } \\
\text { Williams \& Gatenby, 2010; Jiang, Lepak, Hu, et al., 2012; Ramsay et al., } \\
\text { 2000; Sarikwal \& Gupta, 2013) }\end{array}$ \\
\hline & Trust in Management & (Bainbridge, 2015; Boselie et al., 2005; Harney \& Jordan, 2008) \\
\hline & Job Satisfaction & $\begin{array}{l}\text { (Boon et al., 2014; Boselie et al., 2005; Choi \& Yoon, 2015; Claudia, 2015; } \\
\text { Drummond \& Stone, 2007; Fu et al., 2013; Ganli et al., 2014; Gould- } \\
\text { Williams \& Gatenby, 2010; Innocenti et al., 2011; Jiang, Lepak, Hu, et al., } \\
\text { 2012; Ming et al., 2014; Vermeeren et al., 2014) }\end{array}$ \\
\hline & $\begin{array}{c}\text { Organization Citizenship } \\
\text { Behavior (OCB) }\end{array}$ & $\begin{array}{l}\text { (Boselie et al., 2005; Boselie, 2010; Harney \& Jordan, 2008; Jiang, Lepak, } \\
\text { Hu, et al., 2012) }\end{array}$ \\
\hline & Absenteeism & $\begin{array}{l}\text { (Boselie et al., 2005; Ramsay et al., 2000; Sarikwal \& Gupta, 2013; Sterling } \\
\text { \& Boxall, 2013) }\end{array}$ \\
\hline & Innovative Behavior & $\begin{array}{l}\text { (Armstrong et al., 2010; Ehrnrooth \& Björkman, 2012; Jiang, Lepak, Hu, et } \\
\text { al., 2012; Katou \& Budhwar, 2010; Schimansky, 2014; Shin et al., 2016) }\end{array}$ \\
\hline & Employee commitment & $\begin{array}{l}\text { (Bal \& De Lange, 2015; Block \& Pickl, 2014; Boselie et al., 2005; Boselie, } \\
\text { 2010; Ganli et al., 2014; Gould-Williams \& Gatenby, 2010; Harney \& } \\
\text { Jordan, 2008; Innocenti et al., 2011; Jiang, Lepak, Hu, et al., 2012; Ming et } \\
\text { al., 2014; Raidén et al., 2006; Renwick et al., 2012; Ruzic, 2015; Shin et al., } \\
\text { 2016; Tuuli \& Rowlinson, 2009) }\end{array}$ \\
\hline & Extra-effort & (Boon et al., 2014; Knies \& Leisink, 2014) \\
\hline & Organizational climate & (Guerci et al., 2015; Jiang, Lepak, Hu, et al., 2012) \\
\hline & Employee retention & (Alagaraja, 2012; Drummond \& Stone, 2007) \\
\hline
\end{tabular}

Table 7. Performance Outcomes 


\subsection{Is the AMO framework a summative or a multiplicative model?}

Scholars have considered the AMO framework from three different perspectives: multiplicative, summative and combinative. By now, they have not reached an agreement to determine which of these perspectives better explains the interaction between ability, motivation and opportunity dimensions. Indeed, it is possible that AMO dimensions combine differently depending on the level of analysis (Kim et al., 2015). Moreover, some authors maintain that the exact relationship between the three AMO dimensions remains so far unknown (Knies \& Leisink, 2014). Similarly, other authors point out that either the model has never fully empirically tested or the three dimensions have been only independently empirically validated (Demortier et al., 2014).

On the one hand, some authors point out that it is a multiplicative model. That is to say, abilities, opportunities, and motivation must all be present (at least to some degree), and the lack of any of them implies that performance becomes unfeasible (Blumberg \& Pringle, 1982; Bos-Nehles et al., 2013; Delery, 1998; Ozcelik \& Uyargil, 2015; Siemsen, Roth \& Balasubramanian, 2008; Vroom, 1964). Moreover, each of the three dimensions reinforces the other two and, therefore, low levels in one dimension will lead to poor firm performance (Kim et al., 2015). In the extreme situation of one factor being absent, then performance becomes zero (Charles, Blumberg, Pringle \& Charles, 1986; Ozcelik \& Uyargil, 2015). This model is usually known as interactive (or complementary) model, and may be reflected by the function: $\mathrm{P}=\mathrm{f}(\mathrm{A} \times \mathrm{M}$ x O) (Bos-Nehles et al., 2013; Kim et al., 2015).

Some scholars argue that there is a lack of research confirming the multiplicative perspective (Obeidat et al., 2010), or even consider that it has never been empirically demonstrated (Bos-Nehles et al., 2013; Siemsen, Roth, \& Balasubramanian, 2008). In fact, we only found four articles within our review protocol testing the multiplicative hypothesis.

Kim et al. (2015) conducted an investigation in the Korean firm context, considering cross-cultural competences as Abilities, collaborative climate as Motivation, and firm level of internationalization as Opportunity. They tested three different AMO models and found that companies perform better, and employees are more willing to share their expertise when they grant a highly supportive climate, and also provide adequate internationalization levels to their staff to develop their professional skills. On the contrary, high global competence employees may become frustrated in environments that do not provide enough internationalization opportunities, leading to poor firm performance.

In the same vein, Obeidat et al. (2010) conducted a research for providing empirical verification of the AMO model. In fact, they postulated that the three-factor model was better than a one or two-factor 
model for explaining the link between human resources practices dimensions and performance indicators. This hypothesis was validated in the study, providing empirical verification of the multiplicative model.

Also, Bello-Pintado (2015) developed a theoretical model for explaining how the interaction between bundles of HRM practices may affect performance outcomes in the Uruguayan Manufacturing industry context. As a result, they explored the three interaction model ( $\mathrm{x} \mathrm{M} \times \mathrm{O})$. In addition, due to the complexity of studying the interaction between a large number of practices, they decided to study twoway interactions as well (i.e. motivation and ability practices). Contrary to their expectations, they concluded that only the motivation-enhancing bundle had a considerable effect on performance. Moreover, their findings revealed synergistic effects of two-way interactions, but generally with the presence of motivation-enhancing practices. That is to say, performance may be reflected by the functions: $\mathrm{P}=(\mathrm{M} \times \mathrm{O})$ and $\mathrm{P}=(\mathrm{M} \times \mathrm{A})$. Concerning the three-way interaction, they concluded that performance does not improve with a third bundle of HRM practices. That is to say; they did not find a synergistic relationship among ability, motivation and opportunity-enhancing practices.

Similarly, Gould-Williams and Gatenby (2010) conducted an investigation to evaluate the effects of teamwork and organizational context on the performance outcomes of British public workers. Specifically, they tested whether or not the interaction effect of bundles of practices on organizational performance was greater than the individual effects. They used training and development activities as ability-enhancing practices (A), performance-reward activities and performance appraisals as motivation-enhancing practices $(\mathrm{M})$, and team working and high-involvement climate as opportunityenhancing practices $(\mathrm{O})$. Also, they considered commitment, job satisfaction and intention to quit, among other, as organizational performance indicators. Although they used a multiplicative model, it was based on two-way interaction so we cannot, therefore, consider the study as valid for testing the multiplicative model. Moreover, the interactive effects were non-significant to demonstrate positive effects in their statistical analysis.

On the other hand, some scholars consider that performance is better described by an additive function of the form $\mathrm{P}=\mathrm{f}(\mathrm{A}+\mathrm{M}+\mathrm{O})$ (Bos-Nehles et al., 2013; Boxall \& Purcell, 2003). In such a way, the level of performance could increase by fostering independently any AMO dimension, and low levels in one or even two dimensions can be compensated by higher levels in the others (Kim et al., 2015). Moreover, other authors propose that each dimension of the AMO model is aimed at different goals and, therefore, it could be possible to find organizations in which only ability, motivation or opportunity-enhancing practices are taken into consideration (Kroon et al., 2013). As a matter effect, a 
study show that ability and motivation-enhancing practices have a direct effect on the behavior, whereas opportunity-enhancing practices have an indirect effect through commitment (Knies \& Leisink, 2014). We argue, however, that initial minimal levels of each dimension are needed for improving performance. Actually, a motivated employee is not likely to perform better if does not have the minimum abilities for developing the task.

In our review protocol, most of those studies that provide a statistical analysis for measuring the HR practices-performance linkage follow a summative model. That is to say, they usually consider separate HR practices according to each of the three dimensions, for measuring performance independently.

As a matter of fact, Boselie (2010) conducted an investigation in a Dutch hospital, with the aim of studying the effects of HPW practices on both citizenship behavior and commitment. Their hypotheses aimed to find out whether high scores on perceived HPWPs that either enhance abilities (e.g. training), motivation (e.g. pay for performance), or opportunities to participate (e.g. autonomy), were positively related to the above measures of performance. In fact, their findings showed that although abilities and opportunity-enhancing practices were related to high affective commitment, motivation-enhancing practices did not appear to make a significant contribution.

In the same vein, Ganli et al. (2014), conducted a study within the Chinese context to determine the impact of HPWS to job satisfaction, commitment and empowerment. As in the example above, they examined the effect of every dimension separately to each of the measures of performance. Their results, in this case, indicated for example that motivation and opportunity were positively associated with job satisfaction, but they did not find enough evidence concerning ability-enhancing practices.

Furthermore, Jiang, Lepak, Hu et al. (2012), developed a meta-analysis for examining the effect of the three dimensions on proximal (e.g. motivation) and distal (e.g. financial outcomes) organizational outcomes. Their conclusions showed for example that ability-enhancing practices were less positively related to employee motivation than the other two dimensions.

Likewise, other authors followed the same approach in different contexts. Either to examine the impact of these practices on organizational climate (Guerci et al., 2015), and job satisfaction (Ming et al., 2014), or for exploring the mediating effect of these practices between empowerment and performance behaviors (Tuuli \& Rowlinson, 2009).

Similarly, our review protocol reveals that other authors have selected practices from the three dimensions to build a unitary bundle (e.g. (Armstrong et al., 2010; Bainbridge, 2015; Bal \& De Lange, 
2015; Choi, 2014; Sarikwal \& Gupta, 2013). However, although they test all the practices as a whole in their analysis, the individual effect of ability, motivation and opportunity on performance (as well as the interaction among them) remains unclear. That is to say; it is impossible to know if any of the dimensions present insufficient levels, or if performance is affected only by, for instance, motivationenhancing practices. Moreover, they do not perform a statistical analysis in which a combinative approach is explicitly conducted. Therefore, we have classified those studies as either summative or undetermined.

Finally, other authors argue that some dimensions prevail over the others. Therefore, AMO model should be represented by combining additive and multiplicative model (combinative approach). That is to say; there are factors that directly influence performance, while others only moderate them by increasing or decreasing the effects. Although we did not find many examples of the combinative perspective in our review protocol, it is interesting to point them out for analyzing the AMO model in a comprehensive manner.

As a matter of fact, Bos-Nehles et al. (2013) consider that ability is an indispensable requirement for ensuring performance. Motivation and opportunity, on the other hand, are also important, but they cannot directly influence performance when the necessary abilities are not guaranteed. As a result, they believe that AMO framework is better described by the function $\mathrm{P}=\mathrm{f} \mathrm{A}(1+\mathrm{M}+\mathrm{O})$. To support their hypotheses, they applied the AMO theory to study its effect on line's manager performance. Their results showed that performance was better explained by the function $\mathrm{P}=\mathrm{f} \mathrm{A}(1+\mathrm{O})$, that is to say, motivation effect was not significant or even negatively related to performance (Bos-Nehles et al., 2013).

Similarly, other authors consider that motivation is the dimension that has a direct effect on performance (here behavior), whereas both ability and opportunity moderate the motivation effect (Hughes, 2007). In the same vein, other authors suggest that ability and motivation have a direct impact on performance, and the opportunity to perform moderates the motivation effect (Knies \& Leisink, 2014). Also in the same vein, Kim et al. (2015) consider that opportunity and motivation dimensions alone are not likely to have a significant effect on performance. However, as we explained above, their investigation within the Korean context supported the three-way multiplicative approach.

As commented before, other authors have found synergistic effects on two-way interactions (BelloPintado, 2015; Gould-Williams \& Gatenby, 2010). Hence, we consider that these analyses are more related to the combinative model than the multiplicative one. 


\section{Conclusions}

High-performance work systems are supposed to affect organization performance positively. However, there is not a consensus for explaining how these systems work and, indeed, many investigations have been conducted to clarify this issue. Since its emergence, the AMO framework has been widely accepted for explaining the HRM-performance linkage, and most of the articles related to the topic mention it in their theoretical framework section. The model suggests that employees perform well when they have the necessary abilities, the adequate motivation, and their employers provide opportunities to participate.

Appelbaum et al. (2000) originally developed the model on the basis of a framework proposed by Bailey (1993). With the aim of verifying this model, the authors conducted a multilevel research within three different industries operating in the United States context. Overall, they demonstrated that HPWS had a positive effect on various measures of organization performance in each industry and, hence, they validated the AMO framework. However, it remains unclear whether this model is useful for explaining the HRM-performance linkage in all contexts. Moreover, it seems that few researchers have tried to validate the model by following a single methodological approach.

The purpose of our study was to shed light on some aspects of the AMO framework within the HRM context. Specifically, we aimed to identify whether or not it is possible to confirm the model as it was originally proposed. As a result, we conducted a systematic literature review seeking to determine those studies testing the model in their empirical analysis. Likewise, we also aimed to find out which HR practices and measures of performance were considered across investigations, to define if possible a standard approach.

During the curse of this review, we realized that few investigations had the explicit objective of verifying the AMO framework. We cannot say for sure that our review protocol collected all the studies related to the model. Still, it would surprise the existence of many more investigations related to the topic and, even so, we believe that the sample obtained represents as adequately as possible the current state of the art. Consequently, it appears to be a lack of research in this sense. However, most of the articles measured the relationship between HR practices and several measures of performance. That is to say; although those studies did not have the explicit objective of confirming the AMO framework, they indirectly tested it through empirical analysis, in which they used examples of ability, motivation, and opportunity-enhancing practices for exploring their influence over several outcomes. 
The overall conclusion of our study is that accurately determine the effect of HRM over performance is a complex and challenging task. First, this linkage has been investigated from different approaches, by using a large variety of methodologies. In fact, scholars have used various performance measures, different control and contingent factors, and a wide range of human resources practices across investigations. As a result, although many studies confirm the positive effect of HPWS over performance, it becomes impossible to generalize on how a perfect model should be work in all contexts. Also, other mechanisms could either reinforce or complement the AMO model proposal. For instance, the contingent framework underlines the importance of contextual factors, whereas the social exchange theory emphases on the importance of the subjective perceptions of the employees when implementing HR practices. Besides, other approaches consider aspects such the role of line managers in the implementation process, the generational and cultural differences among employees or the firm's available resources for investing in HRM activities. On these grounds, we consider that although the AMO framework is a very useful tool for exploring the HRM-performance linkage, other factors must also be taken into account for defining a more comprehensive approach.

Second, most investigations in the HRM context are based on cross-sectional data, which is useful for determining the influence of HR practices over performance outcomes at a given point of time. Moreover, these studies usually collect data at different levels of the organization or even among different industry sectors, which provides a more comprehensive view and enables generalization of findings. However, few empirical works are using a longitudinal approach and, therefore, it is difficult to establish causal relationships resulting from the implementation of HPWS after a period. From our point of view, it is necessary to conduct more longitudinal analyses for comparing the primary measures with those obtained once HRM actions are implemented.

Third, the vast diversity of methodologies used across investigations involve the utilization of different data and, therefore, provides diverse results. On the one hand, this is a positive fact, because it enriches the model implementation and draws results from a wide range of contexts. However, on the contrary, this tendency of constantly develop new approaches makes it difficult to state firm conclusions concerning the validity of the model, which might result in a lack of scientific confirmation. For this reason, we believe that there is a need for greater consistency among investigations. That is to say, it is necessary to replicate studies within different contexts, for drawing more comparable and precise conclusions.

Finally, it seems that the AMO framework is far from being a static model. In fact, the model has evolved over successive investigations and scholars have pointed out potential improvements to it. As a 
result, it was difficult to find studies replicating the original investigation and, therefore, it is also difficult to know whether or not the model has been tested and validated as it was first conceived.

Concerning the model characteristics and implications, we also identified several concerns. On the one hand, the AMO framework proposes three broad dimensions for classifying human resources practices: ability, motivation, and opportunity. Nevertheless, we consider that the boundaries of these dimensions are often diffuse. As a matter of fact, motivation might be enhanced by using specific motivationenhancing practices such as pay for performance or a formal reward system. However, it can also be improved by challenging jobs, involvement in the decision-making process and information sharing, which are commonly classified as opportunity-enhancing practices. In the same way, skills and abilities might be ensured by formal training or proper recruitment practices, but they might also be enhanced by participative practices such as self-directed work teams, in which employees learn from their fellow workers. This fact reinforces the synergistic hypothesis related to HPWS, and could better explain why summative approaches demonstrate positive effects by using solely one or two dimensions of the AMO model.

On the other hand, we expected to find out more studies testing the interactive approach of the AMO framework, due to the model is supposed to confirm the synergistic effects hypothesized by many scholars. In fact, the authors initially stated that "workers needed appropriate motivation to put forth discretionary effort, they needed to have the necessary skills to make their effort meaningful, and employers had to give them the opportunity to participate..." (Appelbaum et al., 2000), which appeared to support the interactive approach. Therefore, the lack of research testing the multiplicative perspective of the model is a surprising finding, and might challenge most of the assumptions taken into account so far.

Finally, we believe that the AMO model is an excellent and structured framework that provides a better understanding of the relationship between HRM and performance. Moreover, the effectiveness of the model's proposal appears to be beyond doubt. In fact, a well trained and skilled employee will perform better, and a motivated worker will be ready to "go the extra mile". Likewise, if the work environment does not provide adequate opportunities, both abilities and motivation might become meaningless. However, we consider that many other factors could influence the positive effects of HPWS. As a matter of fact, not only contextual factors, but also individual beliefs, personal affinities, or personal circumstances (among others) might affect the implementation of these practices and the subsequent outcomes. For this reason, we consider that developing an HRM model that perfectly fit any situation is a very complicated, if not impossible, task. 
To sum up, we have tried to clarify several issues related to the AMO framework, by exploring investigations linked to the model to a greater or lesser extent. As we commented before, few studies explicitly test the model and, consequently, some of the assumptions remain unclear. Keeping this in mind, further empirical research could be linked to look for new studies that help us to understand better the model. One starting point could be the revision of the studies retrieved through our snowball strategy.

Also, further studies could be devoted to replicate within different contexts those investigations that have demonstrated positive results. By doing that, it could be possible to strengthen the conclusions obtained and take further steps for unlocking the so-called "black box" of human resource management.

\section{References}

Alagaraja, M. (2012). HRD and HRM Perspectives on Organizational Performance: A Review of Literature. Human Resource Development Review, 12(2), 117-143. http://dx.doi.org/10.1177/1534484312450868

An, Y. (2009). The enterprise high-performance work system and its enlightenment to enterprises of our country. In 2009 International Conference on Information Management, Innovation Management and Industrial Engineering, ICIII 2009 (4, 26-29). 10662 Los Vaqueros Circle, PO BOX 3014, Los Alamitos, CA 90720-1264 USA: IEEE. http://dx.doi.org/10.1109/ICIII.2009.468

Appelbaum, E., Bailey, T., Berg, P., \& Kalleberg, A.L. (2000). Manufacturing advantage: Why highperformance work systems pay off. London: ILR Press.

Armstrong, C., Flood, P.C., Guthrie, J.P., Liu, W., MacCurtain, S., \& Mkamwa, T. (2010). The impact of diversity and equality management on firm performance: Beyond high performance work systems. Human Resource Management, 49(6), 977-998. http://dx.doi.org/10.1002/hrm.20391

Arthur, J.B. (1994). Effects of human resource systems on manufacturing performance and turnover. Academy of Management Journal, 37(3), 670-687. Retrieved from: https://www.google.es/search?q=Walton, + R.E. $+(1985),+\% \mathrm{E} 2 \% 80 \% 9 \mathrm{CFrom}+$ control + to + commitment + in + the + workplace $\% \mathrm{E} 2 \% 80 \% 9 \mathrm{D}$, + Harvard + Business + Review,++ March-April, + pp. $.+77-84 . \&$ ie $=$ utf-8\&oe $=$ utf$\underline{8 \& g w s \quad \mathrm{rd}=\mathrm{cr} \& \mathrm{ei}=\mathrm{OFsmV} 9 j \mathrm{LEYXZU} \text { aQj9gF\#q }=\text { Arthur } \% 2 \mathrm{C}++\mathrm{J} . \mathrm{B} .++(1994) \% 2 \mathrm{C}++\% \mathrm{E} 2 \% 80 \% 9}$

Bailey, T. (1993). Discretionary effort and the organization of work: Employee participation and work reform since Hawthorne. Teachers College and Conservation of Human Resources, Columbia University. Retrieved from: https://books.google.es/books?id=KCoiMwEACAAJ 
Bainbridge, H. (2015). Devolving people management to the line. Personnel Review, 44(6), 847-865. http://dx.doi.org/10.1108/PR-10-2013-0193

Bal, P.M., \& De Lange, A.H. (2015). From flexibility human resource management to employee engagement and perceived job performance across the lifespan: A multisample study. Journal of Occupational and Organizational Psychology, 88(1), 126-154. http://dx.doi.org/10.1111/joop.12082

Baltes, P.B. (1997).On the incomplete architecture of human ontogeny. Selection optimization and compensation as foundation. American Psychologist, 52, 366-380. http://dx.doi.org/10.1037/0003066X.52.4.366

Bayo-Moriones, A., \& Galdon-Sanchez, J.E. (2010). Multinational companies and high-performance work practices in the Spanish manufacturing industry. The International Journal of Human Resource Management, 21(8), 1248-1271. http://dx.doi.org/10.1080/09585192.2010.483848

Becker, T. (1992). Foci and bases of commitment: are they distinctions worth making?. Academy of Management Journal, 35(1), 232-244. http://dx.doi.org/10.2307/256481

Bello-Pintado, A. (2015). Bundles of HRM practices and performance: Empirical evidence from a Latin American context. Human Resource Management Journal, 25(3), 311-330. http://dx.doi.org/10.1111/17488583.12067

Blau, P.M. (1964). Exchange and Power in Social Life. New York, NY: Wiley.

Block, J., \& Pickl, S. (2014). The Mystery of Job Performance: A System Dynamics Model of Human Behavior The Black-Box of HRM. The 32nd International Conference of the System Dynamics Society, 1-28. Retrieved from: http://www.systemdynamics.org/conferences/2014/proceed/papers/P1124.pdf

Blumberg, M., \& Pringle, C. (1982). The missing opportunity in organizational research: Some implications for a theory of work performance. Academy of Management Review, 7(4), 560-569. Retrieved from: http://amr.aom.org/content/7/4/560.short

Boon, C., Belschak, F.D., Hartog, D.N., \& Pijnenburg, M. (2014). Perceived Human Resource Management Practices: Their Effect on Employee Absenteeism and Time Allocation at Work. Journal of Personnel Psychology, 13(1), 21-33. Retrieved from: http://www.narcis.nl/publication/RecordID/oai \%3Auva.nl\%3A416712 http://dx.doi.org/10.1027/1866-5888/a000101

Boselie, P. (2010). High performance work practices in the health care sector: A Dutch case study. International Journal of Manpower, 31(1), 42-58. http://dx.doi.org/10.1108/01437721011031685 
Boselie, P., Dietz, G., \& Boon, C. (2005). Commonalities and contradictions in HRM and performance research. Human Resource Management Journal, 15(3), 67-94. http://dx.doi.org/10.1111/j.17488583.2005.tb00154.x

Bos-Nehles, A.C., Van Riemsdijk, M.J., \& Kees Looise, J. (2013). Employee perceptions of line management performance: Applying the AMO theory to explain the effectiveness of line managers' HRM implementation. Human Resource Management, 52(6), 861-877. http://dx.doi.org/10.1002/hrm.21578

Bowen, D., \& Ostroff, C. (2004). Understanding HRM-firm performance linkages: The role of the "strength" of the HR system. Academy of Management Review, 29, 2013-2221.

Boxall, P., \& MacKy, K. (2009). Research and theory on high-performance work systems: Progressing the high-involvement stream. Human Resource Management Journal, 19(1), 3-23. http://dx.doi.org/10.1111/j.1748-8583.2008.00082.x

Boxall, P., \& Purcell, J. (2003). Strategy and human resource management. London: Palgrave Macmillan.

Boxall, P., Purcell, J., \& Wright, P.M. (2009). Human Resource Management. In Strategic HRM (Vol. Human Resource Management, 1-11). http://doi.org/10.1093/oxfordhb/9780199547029.003.0001

Boxall, P., \& Steeneveld, M. (1999). Human resource strategy and competitive advantage: A longitudinal study of engineering consultancies. Journal of Management Studies, 36(4), 443-463. http://dx.doi.org/10.1111/1467-6486.00144

Charles, D., Blumberg, M., Pringle, C.D., \& Charles D. (1986). The Missing Opportunity in Organizational Research: Some Implications for a Theory of Work Performance. Academy of Management Review, 7(4), 560-569. http://dx.doi.org/10.5465/AMR.1982.4285240

Choi, J.-H.. (2014). The HR-performance link using two differently measured HR practices. Asia Pacific Journal of Human Resources, 52(3), 370-387. http://dx.doi.org/10.1111/1744-7941.12009

Choi, M., \& Yoon, H.J. (2015). Training investment and organizational outcomes: A moderated mediation model of employee outcomes and strategic orientation of the HR function. The International Journal of Human Resource Management, (June 2015), 1-20. http://dx.doi.org/10.1080/09585192.2014.1003084

Claudia, A.C. (2015). Hrm - Well-Being At Work Relation. A Case Study. Annals - Economy Series, 4, 140-145. Retrieved from: http://ideas.repec.org/a/cbu/irnlec/y2015v4p140-145.html

Delery, J.E. (1998). Issues of fit in strategic human resource management: Implications for research. Human Resource Management Review, 8(3), 289-309. http://dx.doi.org/10.1016/S1053-4822(98)90006-7

Delgado Rodríguez, M. (2010). Revisión sistemática de estudios: Metaanálisis. Barcelona: Signo. 
Della Torre, E., \& Solari, L. (2013). High-performance work systems and the change management process in medium-sized firms. The International Journal of Human Resource Management, 24(13), 2583-2607. http://dx.doi.org/10.1080/09585192.2012.744337

Demortier, A.-L., Delobbe, N., \& El Akremi, A. (2014). Opening the Black Box of Hr Practices Performance Relationship: Testing a Three Pathways Amo Model. Academy of Management Annual Meeting Proceedings, (M), 1201-1206. http://dx.doi.org/10.5465/ambpp.2014.102

Drummond, I., \& Stone, I. (2007). Exploring the potential of high performance work systems in SMEs. Employee Relations, 29(2), 192-207. http://dx.doi.org/10.1108/01425450710720011

Ehrnrooth, M., \& Björkman, I. (2012). An Integrative HRM Process Theorization: Beyond Signalling Effects and Mutual Gains. Journal of Management Studies, 49(6), 1109-1135. http://dx.doi.org/10.1111/j.1467-6486.2012.01055.x

Einsenberger R., Huntington, R., Hutchison, S., \& Sowa, D. (1986) Perceived organizational support. Journal of Applied Psychology, 71, 500-507. http://dx.doi.org/10.1037/0021-9010.71.3.500

Fields, D.L. (2002). Taking the measure of work: A guide to validated scales for organizational research and diagnosis. Thousand Oaks, Ca: SAGE Publications, Incorporated. http:/ /dx.doi.org/10.4135/9781452231143

Fu, N., Flood, P.C., Bosak, J., Morris, T., \& O’Regan, P. (2013). Exploring the performance effect of HPWS on professional service supply chain management. Supply Chain Management-an International Journal, 18(3), 292-307. http://dx.doi.org/10.1108/SCM-04-2012-0118

Ganli, L., Long, Y., \& Ming, G. (2014). Effect Of High Performance Work System On Organizational Citizenship Behaviors From China. Pakistan Journal of Statist, 30(5), 911-922.

Gardner, T.M., Moynihan, L.M., Park, H.J., \& Wright, P.M. (2001). Beginning to unlock the black box in the HR firm performance relationship: The impact of HR practices on employee attitudes and employee outcomes. CAHRS Working Paper Series, 01(12), 1-43. Retrieved from: http://digitalcommons.ilr.cornell.edu/cgi/viewcontent.cgi?article=1074\&context=cahrswp

Gerhart, B. (2005). Human resources and business performance: Findings, unanswered questions, and an alternative approach. Management Revue, 16(2), 174-185.

Gilbert, C., De Winne, S., \& Sels, L. (2015). Strong HRM processes and line managers' effective HRM implementation: A balanced view. Human Resource Management Journal, http://dx.doi.org/10.1111/17488583.12088 
Godard, J. (2000). High Performance and the Transformation of Work-The Implications of Alternative Work Practices for the Experience and Outcomes of Work. Industrial and Labor Relations Review, 54(4), 776. http://dx.doi.org/10.1177/001979390105400402

Godard, J. (2001). Beyond the High Performance Paradigm? An Analysis of Variation in Canadian Managerial Perceptions of Reform Programme Effectiveness. Journal of Industrial Relations, 39(1), 25. http://dx.doi.org/10.1111/1467-8543.00188

Gould-Williams, J.S., \& Gatenby, M. (2010). The Effects Of Organizational Context And Teamworking Activities On Performance Outcomes. Public Management Review, 12(6), 759-787. http://dx.doi.org/10.1080/14719037.2010.488862

Guerci, M., Radaelli, G., Siletti, E., Cirella, S., \& Rami Shani, A.B. (2015). The impact of human resource management practices and corporate sustainability on organizational ethical climates: An employee perspective. Journal of Business Ethics, 126(2), 325-342. http://dx.doi.org/10.1007/s10551-013$1946-1$

Guest, D. (1997). Human resource management and performance: A review and research agenda. International Journal of Human Resource Management, 8(3), 263-376. http://dx.doi.org/10.1080/095851997341630

Guest, D.E. (1999). Human resource management: The workers' verdict. Human Resource Management Journal, 9(3), 5-25. http://dx.doi.org/10.1111/j.1748-8583.1999.tb00200.x

Guest, D.E. (2011). Human resource management and performance: Still searching for some answers. Human Resource Management Journal, 21(1), 3-13. http://dx.doi.org/10.1111/j.1748-8583.2010.00164.x

Guthrie, J.P., Flood, P.C., Liu, W., \& MacCurtain, S. (2009). High performance work systems in Ireland: Human resource and organizational outcomes. The International Journal of Human Resource Management, 20(1), 112-125. http://dx.doi.org/10.1080/09585190802528433

Hackman, J.R., \& Oldham, G.R. (1980). Work redesign. Reading, MA: Addison- Wesley.

Harney, B., \& Jordan, C. (2008). Unlocking the black box: Line managers and HRM-Performance in a call centre context. International Journal of Productivity and Performance Management, 57(4), 275-296. http://dx.doi.org/10.1108/17410400810867508

Hughes, J. (2007). The Ability-Motivation-Opportunity Framework for Behavior Research in IS. 2007 40th Annual Hawaii International Conference on System Sciences (HICSS’07), 1-10.

http://dx.doi.org/10.1109/hicss.2007.518 
Huselid, M.A. (1995). The Impact of Human Resource Management Practices on Turnover, Productivity, and Corporate Financial Performance. Academy of Management Journal, 38(3), 635-672. http://dx.doi.org/10.2307/256741

Hutchinson, S. (2013). Performance management. Chartered Institute of Personnel and Development.

Ichniowski, C., Kochan, T.A., Levine, D., Olson, C., \& Strauss, G. (1996). What works at work: Overview and assessment. Industrial Relations, 35(3), 299-333. Retrieved from: http://www.scopus.com/scopus/inward/record.url?eid=2-s2.0-5544299990\&partner=40\&rel=R4.0.0 http://dx.doi.org/10.1111/j.1468-232x.1996.tb00409.x

Innocenti, L., Pilati, M., \& Peluso, A.M. (2011). Trust as moderator in the relationship between HRM practices and employee attitudes. Human Resource Management Journal, 21(3), 303-317. http://dx.doi.org/10.1111/j.1748-8583.2010.00151.x

Jiang, K., Lepak, D.P., Han, K., Hong, Y., Kim, A., \& Winkler, A.L. (2012). Clarifying the construct of human resource systems: Relating human resource management to employee performance. Human Resource Management Review, 22(2), 73-85. http://dx.doi.org/10.1016/j.hrmr.2011.11.005

Jiang, K., Lepak, D.P., Hu, J., Baer, J. C., Jia, J.U., \& Baer, J.C. (2012). How does human resource management influence organizational outcomes? A meta-analytic investigation of mediating mechanisms. Academy of Management Journal, 55(6), 1264-1294. http://dx.doi.org/10.5465/amj.2011.0088

Juárez Tarrega, A. (2011). Uso de indicadores financieros para evaluar el impacto de las prácticas de alta implicación (Use of financial indicators to evaluate the impact of high involvement work practices). Working Papers on Operations Management, 2(2), 32-43. http://dx.doi.org/10.4995/wpom.v2i2.847

Kalleberg, A.L. (2006). Beyond Profit? Sectoral Differences in High-Performance Work Practices. Work and Occupations, 33(3), 271-302. http://dx.doi.org/10.1177/0730888406290049

Katou, A.A., \& Budhwar, P.S. (2010). Causal relationship between HRM policies and organisational performance: Evidence from the Greek manufacturing sector. European Management Journal, 28(1), 25-39. http://dx.doi.org/10.1016/j.emj.2009.06.001

Kaufman, B.E. (2015). Market competition, HRM, and firm performance: The conventional paradigm critiqued and reformulated. Human Resource Management Review, 25(1), 107-125. http://dx.doi.org/10.1016/j.hrmr.2014.08.001

Kehoe, R.R., \& Wright, P.M. (2013). The impact of high performance human resource practices on employees' attitudes and behaviors. Journal of Management, 39(2), 366-391. 
Kim, K.Y., Pathak, S., \& Werner, S. (2015). When do international human capital enhancing practices benefit the bottom line? An ability, motivation, and opportunity perspective. Journal of International Business Studies, 46(7), 784-805. http://dx.doi.org/10.1057/jibs.2015.10

Knies, E., \& Leisink, P. (2014). Linking people management and extra-role behaviour: Results of a longitudinal study. Human Resource Management Journal, 24(1), 57-76. http://dx.doi.org/10.1111/17488583.12023

Kroon, B., Van De Voorde, K., \& Timmers, J. (2013). High performance work practices in small firms: A resource-poverty and strategic decision-making perspective. Small Business Economics, 41(1), 71-91. http://dx.doi.org/10.1007/s11187-012-9425-0

Lepak, D.P., Liao, H., Chung, Y., \& Harden, E.E. (2006). A Conceptual Review of Human Resource Management Systems in Strategic Human Resource Management Research: Research in Personnel and Human Resources Management. Research in Personnel and Human Resources Management, 25, 217-271. Retrieved from: http://www.emeraldinsight.com/doi/abs/10.1016/S0742-7301\%2806\%2925006-0 http://dx.doi.org/10.1016/s0742-7301(06)25006-0

Luján-García, D.E., Garrido-Vega, P., \& Escobar-Pérez, B. (2015). Advanced production practices and performance: Empirical evidence from Spanish plants. European Accounting and Management Review, 2(1), 59-84.

MacDuffie, J.P. (1995). Human resource bundles and manufacturing performance: Organizational logic and flexible production systems in the world auto industry. Industrial and Labor Relations Review, 48(2), 197-221. http://dx.doi.org/10.1177/001979399504800201

Maclnnis, D.J., \& Jaworski, B.J. (1989). Information Processing from Advertisements: Toward an Integrative Framework. Journal of Marketing, 53(4), 1. http://dx.doi.org/10.2307/1251376

Marín-García, J.A. (2013). What do we know about the relationship between High Involvement Work Practices and Performance? Working Papers on Operations Management, 4(2), 1-15. http://dx.doi.org/10.4995/wpom.v4i2.1552

Marín-García, J.A., \& Conci, G. (2012). Verification of the reflective model of first order factors for reward and empowerment constructs, based on questionnaires derived from Lawler et al. (1991). Journal of Industrial Engineering and Management, 5(2), 473-495. http://dx.doi.org/10.3926/jiem.454

Marín-García, J.A., \& Conci, G. (2013). Validación de un cuestionario para medir el grado de uso de las prácticas de alta implicación de los trabajadores. Intangible Capital, 9(3), 854-882. http://dx.doi.org/10.3926/ic.417 
Marín-García, J.A., \& De Miguel, E. (2001, October 8). La Gestion Participativa en las Grandes Empresas Industriales Españolas: Grado de Uso, Resultados Obtenidos y Comparación Internacional. Universitat Politècnica de València, Valencia (Spain). Retrieved from: https://riunet.upv.es/handle/10251/5845

Marín-García, J.A., Miralles, C., Garcia-Sabater, J.J., \& Perello-Marin, M.R. (2011). Alternative tools to mass production and human performance indicators in sheltered work centers of Valencian community. Journal of Industrial Engineering and Management, 4(3), 467-480. Retrieved from: http:/ /www.scopus.com/inward/record.url?eid=2-s2.0-80755168912\&partnerID=tZOtx3y1 http://dx.doi.org/10.3926/jiem.2011.v4n3.p467-480

Marín-García, J.A., Ramirez Bayarri, L., \& Atares Huerta, L. (2015). Protocol: Comparing advantages and disadvantages of Rating Scales, Behavior Observation Scales and Paired Comparison Scales for behavior assessment of competencies in workers. A systematic literature review. WPOM-Working Papers on Operations Management, 6(2), 49. http://dx.doi.org/10.4995/wpom.v6i2.4032

Medina-López, C., Alfalla-Luque, R., \& Marín-García, J.A. (2011). Research in operations management teaching: Trends and challenges. Intangible Capital, 7(2), 507-548. Retrieved from: http://www.intangiblecapital.org/index.php/ic/article/view/279 http://dx.doi.org/10.3926/ic.2011.v7n2.p507-548

Medina-López, C., Marín-García, J.A., \& Alfalla Luque, R. (2010). Una propuesta metodológica para la realización de búsquedas sistemáticas de bibliografía (A methodological proposal for the systematic literature review). WPOM, 1(2), 13-30. Retrieved from: https://dialnet.unirioja.es/descarga/articulo/4787162.pdf $\backslash$ nhttps://dialnet.unirioja.es/servlet/extart?codigo=4787162 http://dx.doi.org/10.4995/wpom.v1i2.786

Messersmith, J., Patel, P., \& Lepak, D. (2011). Unlocking the black box: Exploring the link between high-performance work systems and performance. Journal of Applied Phycology, 96(6), 1105-1118. Retrieved from: http://psycnet.apa.org/iournals/apl/96/6/1105/ http://dx.doi.org/10.1037/a0024710

Minbaeva, D.B. (2013). Strategic HRM in building micro-foundations of organizational knowledgebased performance. Human Resource Management Review, 23(4), 378-390. http://dx.doi.org/10.1016/j.hrmr.2012.10.001

Ming, G., Ganli, L., \& Fulei, C. (2014). High-Performance Work Systems, Organizational Identification and Job Satisfaction. Pakistan Journal Statistics, 30(5), 751-766.

Munteanu, A. (2014). What Means High Performance Work Practices for Human Resources in an organization. Annals of the University of Petrosani, Economics, 14(1), 243-250. 
Obeidat, M., Bray, M., \& Mitchell, R. (2010). Examining the Link between High Performance Human Resource Practices (HPHRP) and Organisational Performance: Evidence from the Jordanian Manufacturing and Financial Sectors. Anzam Org. Retrieved from: http://www.anzam.org/wpcontent/uploads/pdf-manager/809 ANZAM2010-293.PDF

Ozcelik, G., \& Uyargil, C. (2015). A Conceptual Framework for Line Managers' Hrm Implementation Effectiveness: Integrating Social Context and Amo Theories. Journal of Business Economics \& Finance, 4(2), 289-301. http://dx.doi.org/10.17261/pressacademia.2015211620

Paauwe, J. (2004). HRM and Performance: Achieving Long-Term Viability. Retrieved from: https://books.google.es/books?

hl=en\&lr=\&id=8ApUw5zfX 0 C\&oi=fnd\&pg $=$ PR14\&dq=Paauwe + HRM + and + performance + Achieving + long term+viability\&ots=KvUxG0Yeun\&sig=b19uTgk5rsAxK4fh5DqJMd3WkOc http://dx.doi.org/10.1093/acprof:oso/9780199273904.001.0001

Paauwe, J., \& Boselie, P. (2005). HRM and performance: What next?. Human Resource Management Journal, 15(4), 68-83. http://dx.doi.org/10.1111/j.1748-8583.2005.tb00296.x

Perello-Marin, M.R., \& Ribes-Giner, G. (2014). Identifying a guiding list of high involvement practices in human resource management. WPOM-Working Papers on Operations Management, 5(1), 31-47.

Purcell, J., Kinnie, N., Hutchinson, S., Rayton, B., \& Swart, J. (2003). Understanding the people and performance link: Unlocking the black box. London: CIPD.

Rabl, T., Jayasinghe, M., Gerhart, B., \& Kühlmann, T.M. (2014). A meta-analysis of country differences in the high-performance work system-business performance relationship: The roles of national culture and managerial discretion. The Journal of Applied Psychology, 99(6), 1011-1041. http://dx.doi.org/10.1037/a0037712

Raidén, A.B., Dainty, A.R.J., \& Neale, R.H. (2006). Balancing employee needs, project requirements and organisational priorities in team deployment. Construction Management and Economics, 24(8), 883895. http://dx.doi.org/10.1080/01446190600647191

Ramsay, H., Scholarios, D., \& Harley, B. (2000). Employees and High-Performance Work Systems: Testing inside the Black Box. British Journal of Industrial Relations, 38(4), 501-531. http://dx.doi.org/10.1111/1467-8543.00178

Renwick, D., Redman, T., \& Maguire, S. (2012). Green human resource management: A review and research agenda. International Journal of Management Reviews, 44(January), 0-35. 
Renwick, D., Redman, T., \& Maguire, S. (2013). Green Human Resource Management: A Review and Research Agenda*. International Journal of Management Reviews, 15(1), 1-14. http://dx.doi.org/10.1111/j.1468-2370.2011.00328.x

Ruzic, M.D. (2015). Direct and indirect contribution of HRM practice to hotel company performance. International Journal of Hospitality Management, 49, 56-65. http://dx.doi.org/10.1016/j.ijhm.2015.05.008

Sarikwal, L., \& Gupta, J. (2013). The Impact of high performance Work practices and organisational citizenship Behaviour on Turnover Intentions. Journal of Strategic Human Resource Management, 2(3), 11-19. Retrieved from: http://search.proquest.com/openview/b723d547479f3c4705400d87ab29b703/1?pqorigsite $=$ gscholar

Schimansky, S. (2014, June 30). The Effect of a High-Commitment Work System on Innovative Behavior of Employees. Retrieved from: http://essay.utwente.nl/65249/1/Schimansky BA MB.pdf

Senge, P., Ross, R., Smith, B., Roberts, C., \& Kleiner, A. (1995). La quinta disciplina en la práctica (1a en cast). Barcelona: Ediciones Granica S.A.

Shih, H.-A., Chiang, Y.-H., \& Hsu, C.-C. (2007). Can high performance work systems really lead to better performance?. International Journal of Manpower, 27(8), 741-763. http://dx.doi.org/10.1108/01437720610713530

Shin, S.J., Jeong, I., \& Bae, J. (2016). Do high-involvement HRM practices matter for worker creativity? A cross-level approach. The International Journal of Human Resource Management, 1-26. http://dx.doi.org/10.1080/09585192.2015.1137612

Siemsen, E., Roth, A.V., \& Balasubramanian, S. (2008). How motivation, opportunity, and ability drive knowledge sharing: The constraining-factor model. Journal of Operations Management, 26(3), 426-445. http://dx.doi.org/10.1016/j.jom.2007.09.001

Sterling, A., \& Boxall, P. (2013). Lean production, employee learning and workplace outcomes: A case analysis through the ability-motivation-opportunity framework. Human Resource Management Journal, 23(3), 227-240. http://dx.doi.org/10.1111/1748-8583.12010

Subramony, M. (2009). A meta-analytic investigation of the relationship between HRM bundles and firm performance. Human Resource Management, 48(5), 745-768. http://dx.doi.org/10.1002/hrm.20315

Triandis, H. (1980). Values, Attitudes and Interpersonal Bebavior, Nebraska Symposium on Motivation, 1979: Beliefs, Attitudes and Values (195-259). Lincoln, NE: University of Nebraska Press. 
Tuuli, M.M., \& Rowlinson, S. (2009). Performance consequences of psychological empowerment. Journal of Construction Engineering and Management, 135(12), 1334-1347. http://dx.doi.org/10.1061/ (ASCE)CO.1943-7862.0000103

Twenge, J.M., Campbell, S.M., \& Freeman, E.C. (2012). Generational differences in young adults' life goals, concern for others, and civic orientation, 1966-2009. Journal of Personality and Social Psychology, 102, 1045-1062. http://dx.doi.org/10.1037/a0027408

Vermeeren, B. (2010). Diversity in HRM Implementation and its Effect on Performance. 32nd EGPA Annual Conference Toulouse, France, 8-10 September 2010, 1-25. Retrieved from: http://soc.kuleuven.be/io/egpa/HRM/toulouse/Vermeeren2010.pdf

Vermeeren, B., Kuipers, B., \& Steijn, B. (2014). Does Leadership Style Make a Difference? Linking HRM, Job Satisfaction, and Organizational Performance. Review of Public Personnel Administration, 34(2), 174-195. http://dx.doi.org/10.1177/0734371X13510853

Vroom, V.H. (1964). Work and motivation. Retrieved from: http://doi.apa.org/psycinfo/1964-35027-000

Wall, T.D., \& Wood, S.J. (2005). The romance of human resource management and business performance, and the case for big science. Human Relations, 58(429), 462.

http://dx.doi.org/10.1177/0018726705055032

Wood, S., Burridge, M., Rudloff, D., Green, W., \& Nolte, S. (2015). Dimensions and location of highinvolvement management: fresh evidence from the UK Commission's 2011 Employer Skills Survey. Human Resource Management Journal, 25(2), 166-183. http://dx.doi.org/10.1111/1748-8583.12064

Wright, P.M., \& Boswell, W.R. (2002). Desegregating HRM: A review and synthesis of micro and macro human resource management research. Journal of Management, 28(3), 247-276. http://doi.org/10.1016/S0149-2063(02)00128-9

Wright, P.M., \& Nishii, L.H. (2007). Strategic HRM and organizational behavior: Integrating multiple levels of analysis. CAHRS Working Paper Series, 468. Retrieved from: http://digitialcommons.ilr.cornell.edu/cahrswp/468

Intangible Capital, 2016 (www.intangiblecapital.org) 